\title{
Review Article \\ Biomaterials for Pelvic Floor Reconstructive Surgery: How Can We Do Better?
}

\author{
Giulia Gigliobianco, ${ }^{1}$ Sabiniano Roman Regueros, ${ }^{1}$ Nadir I. Osman, ${ }^{1,2}$ Julio Bissoli, ${ }^{3}$ \\ Anthony J. Bullock, ${ }^{1}$ Chris R. Chapple, ${ }^{2}$ and Sheila MacNeil ${ }^{1}$ \\ ${ }^{1}$ Material Science Engineering, University of Sheffield, Sheffield S1 3JD, UK \\ ${ }^{2}$ Royal Hallamshire Hospital, Sheffield S10 2JF, UK \\ ${ }^{3}$ Hospital das Clínicas da Faculdade de Medicina, Universidade de Sao Paulo, 05410-020 São Paulo, Brazil
}

Correspondence should be addressed to Sheila MacNeil; s.macneil@sheffield.ac.uk

Received 25 June 2014; Accepted 19 August 2014

Academic Editor: Uwe Klinge

Copyright (C) 2015 Giulia Gigliobianco et al. This is an open access article distributed under the Creative Commons Attribution License, which permits unrestricted use, distribution, and reproduction in any medium, provided the original work is properly cited.

\begin{abstract}
Stress urinary incontinence (SUI) and pelvic organ prolapse (POP) are major health issues that detrimentally impact the quality of life of millions of women worldwide. Surgical repair is an effective and durable treatment for both conditions. Over the past two decades there has been a trend to enforce or reinforce repairs with synthetic and biological materials. The determinants of surgical outcome are many, encompassing the physical and mechanical properties of the material used, and individual immune responses, as well surgical and constitutional factors. Of the current biomaterials in use none represents an ideal. Biomaterials that induce limited inflammatory response followed by constructive remodelling appear to have more long term success than biomaterials that induce chronic inflammation, fibrosis and encapsulation. In this review we draw upon published animal and human studies to characterize the changes biomaterials undergo after implantation and the typical host responses, placing these in the context of clinical outcomes.
\end{abstract}

\section{Introduction}

Stress urinary incontinence (SUI) and pelvic organ prolapse (POP) are important health problems that cause a sizable personal, societal, and economic burden [1]. SUI is defined as the "involuntary leakage of urine on exertion, sneezing or coughing" $[2,3]$. POP is the "the descent of one or more of the anterior vaginal wall, posterior vaginal wall, the uterus (cervix), or the apex of the vagina (vaginal vault or cuff scar after hysterectomy)" [4]. SUI and POP are thought to share a common pathogenesis, weakening of the muscular and connective tissues of the pelvic floor. Multiple etiological factors have been implicated including ageing, obesity, pregnancy, and childbirth, as well as genetic factors and menopause $[1,5-7]$.

Following failure of conservative management including physiotherapy, corrective surgery is considered to be the most effective and durable treatment for both SUI and POP. Most of the older surgical techniques relied upon suturing the local tissues to the back of the pubic bone (colposuspension) or using an autologous fascial sling. More recently there has been a growing trend to reinforce repairs using both synthetic and biological materials. This practice has been adapted from hernia surgery where there is established evidence that repairs reinforced with synthetic mesh provide superior outcomes.

Synthetic meshes were popularized in pelvic floor surgery for SUI following the work of Ulmsten and Petros [8]. The mid-urethral tape (MUT) involved a minimally invasive approach to implant a thin synthetic mesh underneath the mid-urethral point. Early reports of cure rates in the range of $80-90 \%$ further propelled the uptake of this technology. Following the early success of MUT and a randomized control trial against colposuspension, synthetic mesh for SUI was soon introduced [9]. This was not based on long term supportive data but rather a grandfather clause which permitted introduction of a new material based on its similarity to an index product, which was used for hernia repair, namely, 
polypropylene mesh. A long term follow-up, the Ward and Hilton [9] study, demonstrated a $4 \%$ exposure of mesh rate. Subsequently mesh was introduced for the treatment of pelvic organ prolapse (POP) and this has resulted in a significant problem with mesh exposure which has led to enormous medico-legal problems, particularly in the United States of America.

The following decade has seen a rapid rise in reports of mesh for POP related complications, but it is clearly important to differentiate mesh exposure (erosion) used for SUI from that used for POP. Thus reports of debilitating complications of vaginal mesh implantation have emerged including vaginal wall erosion $(0-25.6 \%)$, chronic pain (0$5.5 \%)$, and sexual problems (1.9-17\%) [10]. Although it can be debated whether these rates are high, the complications are often difficult to treat, requiring further hospital visits, further tests, and further reconstructive surgery. The situation has not escaped the attention of medical regulatory bodies such as the FDA who have issued statements warning patients and surgeons of the potential dangers of mesh use for POP [11, 12]. More recently there has been a wave of class action litigation law suits raised against device manufacturers by patients who have suffered mesh complications, such that several major manufacturers have withdrawn products from the market.

Biological grafts are alternatives to synthetic mesh. The most commonly used material, autologous fascia, has been used for over 100 years in the treatment of SUI with good efficacy. The main drawback however is the need to harvest the graft from a donor site (fascia lata from the thigh or rectus fascia from the abdominal wall) and potential morbidity (e.g., wound infection, scar, nerve injury, and hernia) [13]. There is a limitation on how much graft can be harvested which precludes its use in POP which is associated with relatively large fascial defects. This can be avoided by using grafts derived from cadavers or alternatively animal derived collagen matrices (e.g., porcine dermis, porcine small intestine, and bovine dermis). However, these materials require extensive processing decellularization, sterilization, and cross-linking processes to resist degradation [14]. While this renders materials nonimmunogenic, it can impact their biomechanical properties [15]. There is also the risk of viral or prion transmission [13]. Clinical studies are limited; however clinical experience is that all of the materials appear to be associated with graft failure in the medium term due to the body's response to the material, leading its encapsulation and subsequent degradation with limited remodeling.

It is likely that biomaterials are subject to multifactorial problems because of (1) their physical properties (e.g., porosity and degradability), (2) their mechanical properties (e.g., stiffness and strength), or (3) the nature of the patient's immune response to the implanted biomaterials. In addition, surgical and patient specific factors (e.g., individual anatomy and comorbidities) are likely to play a role, though these are not modifiable by material design.

To provide a simple context for this review we depict the current hypotheses of how failures of implant might occur through several routes in cartoon form in Figure 1 where the implanted material is shown conceptually as a hammock attached to two trees (the supporting structures of the pelvic floor).

In the case of successful implantation, it is currently thought that the material induces an acute inflammatory response, which leads to constructive remodeling and material integration (Figure $1(\mathrm{~d})$ ).

The aim of this review is to characterize these changes and responses, from the available human and animal studies, and relate them to clinical outcomes, thereby guiding the design of novel materials for this challenging clinical application.

\section{Methods}

The MEDLINE database was searched for articles describing studies investigating the in vivo response to biomaterials used routinely in pelvic floor surgery or that have been studied in the context of clinical trials. The search was limited to the years 1990 to 2013. The following search terms were used: "pelvis," "pelvic floor," "vagina," "in vivo," "in vitro," "biocompatibility," "prolapse," “incontinence," "biomaterial," "sling," "mesh," "polypropylene," "autografts," "allografts," and "xenografts." Abstracts were screened for relevance by 2 reviewers before full articles were retrieved. Articles were included if they described the changes in physical or biomechanical properties of materials after implantation in animals or humans or the histological features of the host response to the implanted material. Implantation sites were restricted to subcutaneous, intravaginal, or abdominal muscles.

\section{Results}

In total 10 studies assessing autologous materials, 11 assessing allograft materials, 24 assessing xenografts, and 24 assessing polypropylene meshes compared with other synthetic meshes were included. These studies are summarized in Tables 2, 3, 4 , and 5 .

\subsection{Biological Materials}

3.1.1. Autologous Materials. Autologous grafts harvested from the rectus fascia and fascia lata have long been used in SUI surgery. A major advantage of autografts over synthetic materials is that erosion is almost unheard of [16]. A possible disadvantage to using autografts is that the connective tissues of patients with SUI may be inherently weak predisposing to failure. Nevertheless the overall long term outcomes with autografts are largely excellent with reported rates of cure generally over $90 \%[17,18]$.

Biomechanical Properties of Autologous Materials. Four studies describing changes in mechanical properties of autologous materials over a 12-16-week period were found. Uniaxial stress strain testing of autologous rectus fascia before and after implantation in rabbit vagina and anterior abdominal wall showed no significant decrease of ultimate tensile strength (UTS) (the maximum stress a material can take before failing) and Young's modulus (YM) (material stiffness), at twelve weeks after implantation $[19,20]$. However, there was a reduction in surface area of the grafts by $50 \%$ 

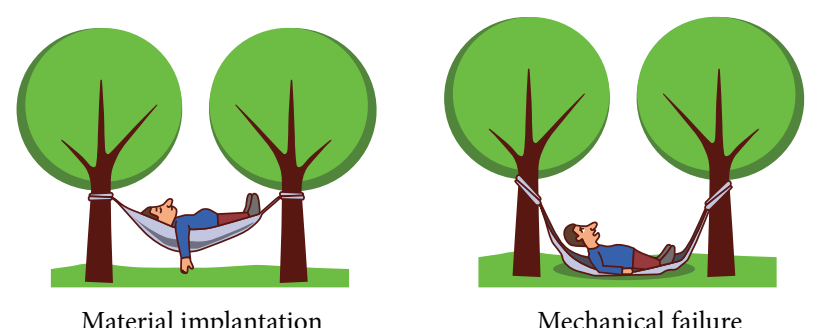

Mechanical failure of the material

(a)
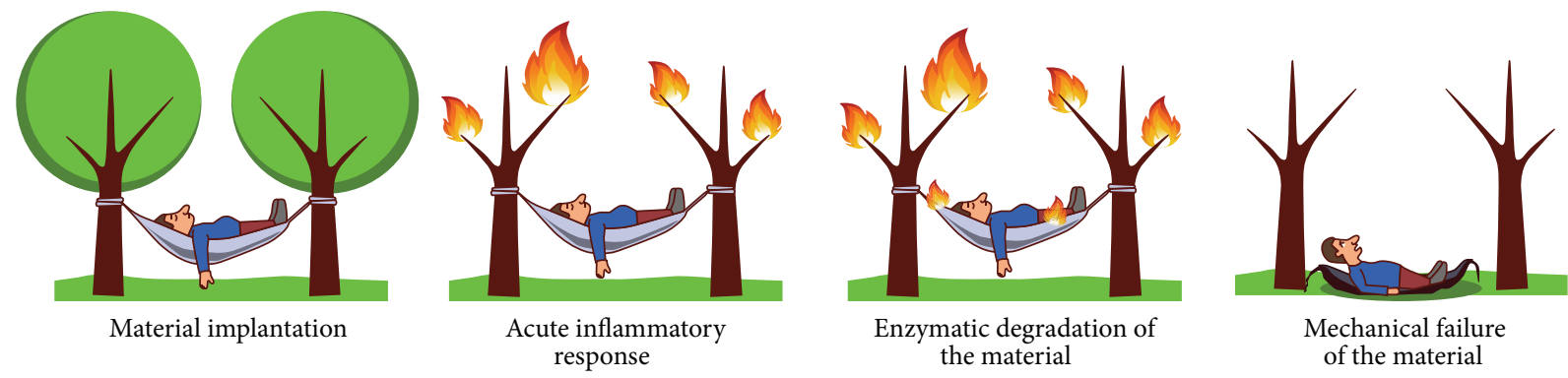

(b)

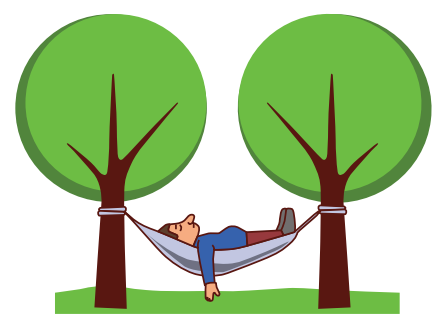

Material implantation

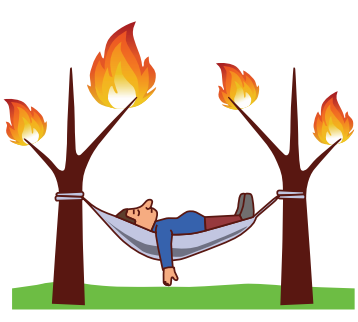

Acute inflammatory response

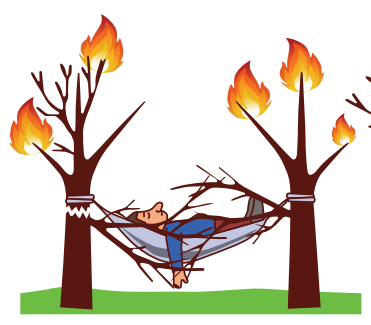

Chronic inflammatory response leading to a fibrotic process

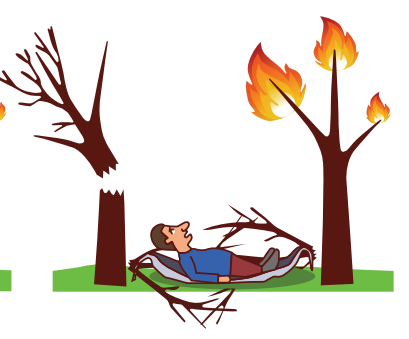

Erosion of native tissues

(c)

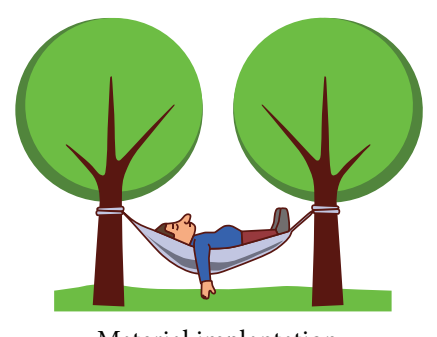

Material implantation

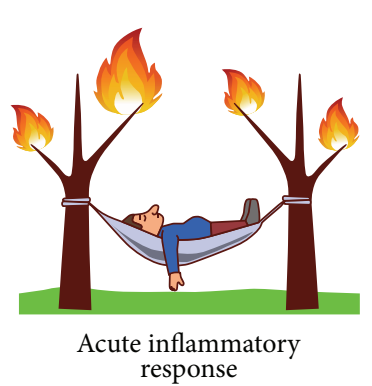

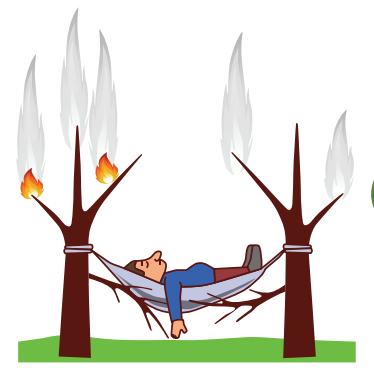

Constructive remodelling

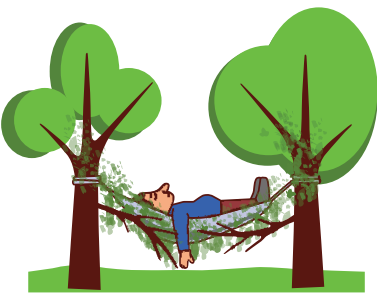

Long term integration into native tissues

(d)

FIGURE 1: Cartoon of how patients can respond to materials implanted in the pelvic floor: (a) mechanical failure, (b) material recognized as non-self and isolated from body tissues with encapsulation, (c) exposure (erosion), and (d) optimal result for implanted material.

suggesting that significant degradation had occurred $[19,20]$. A comparison of mechanical strength of autologous materials used for sling was carried out by Choe et al. [21]. They harvested dermis, rectus fascia, and vaginal mucosa from 20 women undergoing vagina prolapse surgery and they tested displacement and maximum load with the Instron tensiometer. This study showed that fascia lata had the highest mean maximum load to failure $(217 \mathrm{~N})$, followed by human dermis $(122 \mathrm{~N})$, rectus fascia, and vaginal mucosa (both $42 \mathrm{~N}$ ) in women undergoing surgeries for various reasons [21]. Autologous rectus fascia showed no significant decrease in tear resistance using the trouser tear test after 4 months of subcutaneous implantation in rodents [22]. In summary in all four studies there was agreement that the mechanical properties did not change significantly over a 12 - to 16 -week duration [19-22]. 
Host Response to Implanted Autologous Materials. Eight studies analysed the host response to autologous materials over a time period up to 90 days $[19,20,23-29]$. In the majority of studies, unless stated otherwise, biomaterials were assessed after implantation by conventional blindly scored histology (staining of fixed samples by haematoxylin and eosin $(\mathrm{H} \& \mathrm{E}))$, trichromes, and/or the presence of proangiogenic cells.

Hilger and colleagues assessed human cadaveric skin and autologous fascia after implantation in the abdominal and vaginal walls of New Zealand white rabbits. Materials were harvested at 6 and 12 weeks. Histological analysis demonstrated that autologous fascia promoted a relatively minimal inflammatory response and neovascularization but moderate collagen infiltration when compared to fenestrated porcine dermis and porcine collagen-coated polypropylene mesh [20]. Jeong and coworkers described similar results noting minimal inflammatory response and neovascularization in rabbits when autologous fascia was implanted under the eye lid for up to 8 weeks [24].

Two studies assessed histological changes in paravaginal tissue after the implantation of autologous fascial slings for SUI in women. In the study by FitzGerald et al. biopsies of the sling were taken from 5 patients requiring revision surgery due to persistent incontinence. The time since the initial surgery ranged from 3 weeks to 4 years. The grafts explanted after up to 8 weeks showed moderate uniform fibroblast infiltration and neovascularization. Collagen remodelling was evident in parts of the graft biopsied at 4 years, with no evidence of chronic inflammation [23]. Woodruff and colleagues performed a similar study in 24 patients undergoing sling revision for poor efficacy (2 patients), urinary retention (9), and sling obstruction (13), 2-34 months after implantation [27]. All grafts showed moderate uniform fibroblast infiltration and moderate collagen fibers. All grafts showed moderate degradation. There was no evidence of encapsulation.

In summary these eight studies suggest that when autologous fascia is implanted there is a minimal to moderate inflammatory response, a moderate degree of collagen production, and a suggestion that grafts undergo a degree of remodelling over the long term.

3.1.2. Allografts. Allografts used in pelvic floor reconstruction usually consist of fascia. The donors are screened for infectious diseases before the grafts undergo cleaning, freeze drying, and gamma irradiation to eradicate any infective or immunogenic material. A concern with these grafts is that they are often donated by the elderly who have an age related weakening in connective tissues [30]; additionally processing techniques such as freeze drying and solvent dehydration may reduce the tensile strength [31]. Cadaveric grafts are advantageous in that they avoid donor site complications. In terms of efficacy, results are mixed. Some have shown cadaveric fascia to demonstrate similar subjective cure rates to autologous fascia at around $90 \%$ at 2 years [32]. However others have shown that on urodynamic testing $42 \%$ of cadaveric graft patients had SUI whereas no patients with autologous grafts had SUI [33].
Biomechanical Properties of Allografts. Five studies investigated the change in mechanical properties after implantation of allografts in animals. All these studies utilized uniaxial stress strain testing. The time after which samples were explanted ranged from 60 days to 12 weeks [20, 22, 34-36].

After implanting human cadaveric dermis in rabbit vagina, Hilger et al. reported a decrease in ultimate strength of $86.6 \%$ at 12 weeks; in comparison autologous fascia lost only $28.6 \%$ [20]. Conversely, Rice and colleagues found an increase in tensile strength of cadaveric dermis (AlloDerm) from 0.142 to $0.226 \mathrm{MPa}$, increasing by about $80 \%$ of its initial strength, 60 days following subcutaneous implantation [36]. Walter et al. reported that, after 12 weeks, following implantation of cadaveric fascia lata in rabbit vagina, the tensile strength decreased by approximately 90\% [34]. Spiess et al. implanted human cadaveric fascia lata subcutaneously on the abdominal wall of 20 rats randomized into 2 survival groups at 6 and 12 weeks. They found no significant decrease in tensile strength from $0.167 \mathrm{~kg}$ at week 6 and $0.185 \mathrm{~kg}$ at week 12 [35]. Kim et al., similarly, implanted human cadaveric fascia in 20 rats, randomized into 2 survival groups of 2 and 4 months. They found no significant difference in fracture toughness before implantation and after implantation in human cadaveric fascia (from 2120 to $1145 \mathrm{~J} / \mathrm{m}^{2}, P=0.09$ ) [22].

In summary, the available studies show disparate results with respect to the changes in mechanical properties of allografts following implantation. This may be attributable to the heterogeneity in the type of allografts used, the animals studied, the sites of implantation, and the assessment at different time points.

Host Response to Implanted Allografts. In total eight studies assessed the host response to allografts in both animals and humans. The time since implantation ranged from 2 days up to 65 weeks $[20,26,27,36-40]$.

Human cadaveric dermis and cadaveric fascia have been found to be well integrated onto the abdominal wall [37, 40, $41]$ and rectus muscle $[36,38]$ in different animals, including rats, rabbits, and pigs, as noted by moderate fibroblast infiltration, new collagen production, and neovascularization where materials were implanted from 2 days up to 62 weeks. Human cadaveric dermis, after 12 weeks of implantation, was similarly well integrated into vaginal tissues of rabbits. However, it appeared highly fragmented suggesting significant degradation [20]. Krambeck et al. also describe a faster degradation of cadaveric fascia implanted subcutaneously on the abdominal wall of rabbits with a fascial defect for 6 and 12 weeks compared to polypropylene or autologous fascia [26]. VandeVord and colleagues also found moderate cell infiltration and angiogenesis at 12 weeks following the insertion of human cadaveric dermis and cadaveric fascia slings under the bladder neck of rats; however there was a moderate encapsulation after implantation [39]. Finally, in the study by Woodruff et al. in 5 women who received human cadaveric dermis grafts, biopsies 2-65 months after implantation showed significant graft degradation with residual areas of graft appearing acellular and encapsulated [27].

In summary, some studies suggest that allografts demonstrate infiltration by host cells, new collagen production, and 
neovascularization whilst other studies suggest that a variable degree of graft degradation occurs along with encapsulation in the long term. There is a degree of agreement that allograft induces an acute inflammatory response as inflammatory infiltrates have been found populating the grafts.

3.1.3. Xenografts. A number of grafts from animals, mainly porcine and bovine, have been used in pelvic floor surgery. These materials undergo extensive processing after harvesting to decellularize them and render them non-immunogenic. Additionally there are FDA regulations on animal source and vaccination status which must comply with [42]. Porcine dermis may be artificially cross-linked using hexamethylene diisocyanate to make it more resistant to enzymatic digestion [43]. Clinical studies showed lower continence rates for porcine dermis (approx. 80\%) and increased reoperation than that for synthetic tape or autologous fascia [44]. Porcine small intestine submucosa (SIS) has shown cure rates from 79 to $93 \%$ at 2 - and 4 -year follow-up, respectively $[45,46]$. However one study has raised concerns that SIS may not be strictly acellular and may contain porcine DNA [47].

Biomechanical Properties of Xenografts. Nine studies investigated the mechanical properties of xenografts before and after implantation. All these studies assessed either porcine dermal collagen matrix, both cross-linked and non-cross-linked, or porcine small intestine submucosa.

Hilger et al. assessed non-cross-linked porcine dermis xenografts implanted on the abdominal wall and vaginal wall of rabbits. After 12 weeks, half of the grafts implanted in the vaginal wall were absent. The other half as well as grafts implanted into the abdominal wall showed an average reduction of $84.1 \%$ in ultimate strength [20]. Another study assessed the long term mechanical integrity of cross-linked porcine dermis. After 9 months following implantation in the abdominal and vagina walls, grafts had degraded by $36 \%$ and $46 \%$, respectively. When subjected to mechanical testing non-degraded graft fragments showed similar strength compared to baseline values whilst degraded fragments decreased by more than $50 \%$ [48].

Liu and colleagues implanted SIS and porcine dermal collagen matrix in rats with surgically created abdominal wall defects. The maximum load (at failure) at baseline for SIS and dermal collagen matrix was $22.81 \mathrm{~N}$ and $43.16 \mathrm{~N}$, respectively. Following 12 weeks of implantation, there was no significant change in the maximum load of cross-linked porcine dermal collagen matrix and SIS [49]. Similarly other workers observed an increase in the ultimate tensile strength of SIS after 90 days of implantation from a baseline value of 7.5 and $9.8 \mathrm{~N} / \mathrm{cm}^{2}$ at baseline, respectively, to 19.56 and $13.3 \mathrm{~N} / \mathrm{cm}$. These results were averages of 48 implants in rats [50]. Rice et al. also found an increase in tensile strength of SIS after 60 days of implantation in a rat abdominal wall defect from $0.142 \mathrm{MPa}$ at day 0 up to $0.226 \mathrm{MPa}$ after 60 days of implantation [36]. Similarly, Zhang et al. implanted SIS in abdominal wall of rats and they found increased strength for SIS from $0.35 \mathrm{MPa}$ to 0.41 after 4 weeks [51]. Badylak et al. repaired surgically created abdominal wall defects in dogs with SIS $(8 \times 12 \mathrm{~cm})$; they performed serial ball burst strength tests after $1,4,7$, and 10 days and then at 1, 3, 6, and 24 months) [52]. There was an initial decrease in ball burst strength from 73.37 pounds to 39.97 pounds by day 10. After day 10 , the strength began to increase and after 2 years there was an increase to 157.20 pounds in burst strength. Jenkins et al. showed an increase in strength in crosslinked porcine matrices after 6 months of implantation in the preperitoneal area from $0.07 \pm 0.01 \mathrm{~N}$ up to $22.36 \pm 3.3 \mathrm{~N}$ [53]. In contrast, Ko and colleagues found no significant difference in ultimate tensile strength of SIS after 4 months of implantation in a porcine wall defect, with values ranging from 41.3 to $74.8 \mathrm{~N} / \mathrm{cm}^{2}$ [54].

In summary it appears that non-cross-linked porcine dermal collagen matrices are degraded rapidly (within 3 months) and lose most of their mechanical integrity within this period. By contrast cross-linked porcine dermal collagen matrix is more resistant to degradation and maintains its mechanical properties for at least 3 months, whereas SIS appears to increase in strength after as long as 2 years after implantation.

Host Response to Implanted Xenografts. Twenty-four studies assessing the host response to allografts were found. Noncross-linked porcine dermal collagen was assessed in fourteen studies $[20,26,27,36,39,50-52,54-61]$. These studies were performed on rats $[36,50,51,55,58,59]$, dogs [52, 55], pigs [54,57], and rabbits [26] in addition to few clinical studies $[20,27,39,56]$. Cross-linked porcine matrices were assessed in seven studies [40, 49, 53, 62-66]. Animal models mainly used were abdominal defects of rats $[49,62,66]$, rabbits [65], minipigs [53], pigs [40, 63], and primates [64]. Some of these studies looked at the acute response $[39,49,53$, $55,59,66]$; some other studies looked at a more intermediate response (1-3 months) [20, 26, 36, 39, 40, 49-51, 54, 55, 57, 58, $60,62-64,66]$; another looked at longer term response (more than 3-months) [27, 40, 53, 62, 64, 65].

Hilger et al. and Pierce et al. found minimal neovascularization and collagen ingrowth in porcine dermal xenografts $[20,65]$. Both studies agreed that the degradation of porcine dermis is higher when the inflammatory response is high, and it may accelerate this degradation process. They also reported fragments encapsulated, which has been also found in many studies with different species including rats $[39,62]$, rabbits [65], pigs [40], primates [64], and humans [27].

In contrast, non-cross-linked SIS leads to high collagen ingrowth with a moderate degree of remodeling and orientation and high neovascularization $[29,36,39,49-$ $51,54,55,57,63]$. On the other hand, many studies agree with a very rapid degradation of the SIS which is replaced by the host tissue $[49,51,52,55,58,66,67]$. Only two studies reported an absence of host fibroblast infiltration and fibrotic tissue penetration without neovascularization for SIS implanted in rats [62] and rabbits [26]. In humans, Cole et al. performed revision surgery on a patient who had developed a bladder outlet obstruction after SIS implantation and found that the implant had been encapsulated [60]. Nevertheless, other investigators, at 12 and 48 months, respectively, found that the SIS was replaced by native tissue in humans $[56,61]$. 
In summary, the available studies agree that the degree of cross-linkage affects the rate of degradation and the degree of the inflammatory response of the host. Studies on cross-linked xenografts agree that cross-linked collagenous matrices induce little cell infiltration; hence there is limited collagen remodeling and graft degradation. In non-crosslinked xenografts, cell infiltration was greater with faster degradation rate and collagen production.

3.2. Polypropylene Mesh. There is a range of synthetic polypropylene meshes that have been used. These are summarized in Table 1 where they are classified as type 1, 2, 3, or 4 according to their mesh size, where 1 is macroporous $(>75 \mu \mathrm{m})$, 2 is less than $10 \mu \mathrm{m}, 3$ is microporous with microporous compartments, and 4 is nanoporous $(<1 \mu \mathrm{m})$. Thus a wide range of synthetic materials have been investigated for use in the treatment of SUI. These materials offer several advantages including lack of transmission of infectious diseases and ease of availability, as well as the sustainable tensile strength due to their nondegradable nature [68]. Mesh materials have been classified in to 4 groups based on the basis of porosity (microporous or macroporous) and filamentous structure (monofilament of multifilament) [69]. The initial clinical experience with mid-type II (microporous/multifilament fibers, e.g., expanded PTFE) and III (macroporous and microporous/multifilament fibers, e.g., Mersilene) meshes was largely negative with excision rates of up to $30 \%$ for expanded PTFE [70] and erosion rates of $17 \%$ for Mersilene (polyester) [71].

A greater pore size is thought to be advantageous as it allows the admittance of immune cells and greater collagen ingrowth into the construct [13]. This is thought to reduce the risk of mesh infection and accelerate and enhance host tissue integration. Monofilament meshes are thought to reduce the risk of infection in comparison to multifilament meshes. The theoretical concern with the latter is that bacteria may colonize the $10 \mu \mathrm{m}$ subspaces between fibers which are inaccessible for the larger host immune cells (9-20 $\mu \mathrm{m})$ [72]. Today a mid-type I polypropylene mesh that is macroporous and monofilament is most commonly used [73] with cure rates for SUI of $>90 \%$ at 5 years.

Biomechanical Properties of Polypropylene. Seven studies investigated the mechanical properties of polypropylene meshes with implantation times ranging from two weeks in animal models up to two years. Animal models used were rats abdominal wall $[35,74]$, pig preperitoneal implantation [75], rats rectus fascia [76], minipigs hernia repair [77], and ewes abdominal and vaginal walls [78].

Melman et al. tested Bard Mesh, a knitted monofilament mesh made of high molecular weight polypropylene (HMWPP) and Ultrapro, a knitted macroporous composite mesh made of low molecular weight polypropylene (LMWPP) and poliglecaprone (Table 1). They have been implanted in minipigs hernia repair model for up to 5 months. HMWPP mesh decreased from maximal load at failure $59.3 \mathrm{~N}$ at 1 month to $36.0 \mathrm{~N}$ at 5 months, while LWPP mesh decreased from 61.5 to $37.8 \mathrm{~N}$ at 5 months [77]. Long term studies were carried out by Zorn et al. where TVT and SPARC were compared to SIS in a rat abdominal wall defect for up to 12 months. Both TVT and SPARC are macroporous meshes made of polypropylene monofilaments. SPARC did not change its mechanical properties after 12 months of implantation (maximum load at baseline $0.453 \mathrm{~kg}$ and at 12 months $0.497 \mathrm{~kg}$ ). By contrast the maximum load for TVT decreased from $0.779 \mathrm{~kg}$ to $0.523 \mathrm{~kg}$ for TVT and for SIS decreased from $0.402 \mathrm{~kg}$ to $0.174 \mathrm{~kg}$ [74]. Also Bazi et al. showed how similar are the mechanical properties of Gynecare TVT and Advantage, both macroporous polypropylene monofilament meshes, compared with other meshes such as IVS Tunneller, multifilament polypropylene mesh, and SPARC. The lowest, at 25.2 N, was TVT and the highest, 34.9 N, was Advantage, with no significance between them after 24 weeks of implantation in rats rectus fascia [76]. Also other studies agree on these parameters where TVT was found to be able to comply with the highest break load $(0.740 \mathrm{~kg})$, compared to $0.39 \mathrm{~kg}$ for fascia lata after implantation in rats abdominal wall for up to 12 weeks [35], and was said to be less stiff than other synthetic materials used for meshes $(0.23 \mathrm{~N} / \mathrm{mm}$ compared to nylon, $6.83 \mathrm{~N} / \mathrm{mm})$ [79].

A recent study compared two sizes of meshes implanted in two different places in a sheep model. Gynemesh was cut in two sizes $(50 \times 50 \mathrm{~mm}$ and $35 \times 35 \mathrm{~mm})$ and it was implanted in 20 adult ewes, on the abdominal and vaginal walls for a period of 60 and 90 days. Results showed that grafts of both dimensions, implanted on the vaginal wall, were stiffer than the ones implanted on the abdominal wall, after a period of 90 days [78].

However, they all agree that physical characteristics of the mesh, such as monofilament or multifilament, porosity, and polymer molecular weight, hugely affect the mechanical performance of the implants in vivo.

Host Response to the Implanted Polypropylene. Twenty-one papers have looked at the host response to the polypropylene meshes. They have been assessed in various animal models: rats abdominal wall $[50,58,74,80-82]$, rats rectus fascia $[38,76,83]$, rabbits bladder neck [84], rabbits abdominal wall [85], rabbits rectus fascia [26], rabbits vaginas [65, 86], minipigs hernia [77], pigs peritoneum [75, 87], ewes vagina $[78,88]$, and ewes abdominal wall [78] in addition to few clinical studies [27, 89-91]. The studies have looked at acute inflammatory responses to the most commonly used, nondegradable meshes, described in Table 1. Few studies looked at the acute inflammatory response that occurs from the day of implantation up to 30 days [50, 58, 80-82, 85, 88]. Other studies looked at the immediate responses (1-3 months) $[26,75,78,83,84,86,87]$ and longer term responses (>3 months) where fibrosis and chronic inflammation can be seen $[27,65,74,76,77,89-91]$.

A very recent study of Manodoro et al. showed how 30\% of Gynemesh grafts $(50 \times 50 \mathrm{~mm})$, implanted in ewes after 90 days, caused vaginal erosion and exposure. The study also showed that $60 \%$ of the smaller Gynemesh meshes $(35 \times$ $35 \mathrm{~mm}$ ) had a reduced surface (i.e., contracting) after 90 days of implantation [78].

Falconer et al. reported a study on Prolene and Mersilene meshes. The biopsies were stained with Masson's trichrome. 
TABLE 1: Classification of synthetic materials used in pelvic floor reconstruction.

\begin{tabular}{|c|c|c|c|c|c|}
\hline Type & Mesh pore size & Structure & Polymer & Trade name & Company \\
\hline \multirow{25}{*}{ I } & \multirow{25}{*}{$\begin{array}{l}\text { Macroporous } \\
>75 \mu \mathrm{m}\end{array}$} & \multirow{21}{*}{ Monofilament } & \multirow{21}{*}{ Polypropylene } & Uretex & C. R. Bard \\
\hline & & & & Gynecare TVT & $\begin{array}{l}\text { Ethicon, Johnson \& } \\
\text { Johnson }\end{array}$ \\
\hline & & & & Bard Mesh & Bard/Davol \\
\hline & & & & SPARC & American Medical Systems \\
\hline & & & & In-Fast & American Medical Systems \\
\hline & & & & Monarc & American Medical Systems \\
\hline & & & & Lynx & Boston Scientific \\
\hline & & & & Advantage & Boston Scientific \\
\hline & & & & Obtryx & Boston Scientific \\
\hline & & & & Optilene & B. Braun \\
\hline & & & & Aris & Mentor Corp \\
\hline & & & & Perigee & American Medical Systems \\
\hline & & & & Parietene & Covidien \\
\hline & & & & Intepro & American Medical Systems \\
\hline & & & & Gynecare Prolift & $\begin{array}{l}\text { Ethicon, Johnson \& } \\
\text { Johnson }\end{array}$ \\
\hline & & & & Surgipro & Covidien \\
\hline & & & & Prolene & $\begin{array}{l}\text { Ethicon, Johnson \& } \\
\text { Johnson }\end{array}$ \\
\hline & & & & Prolene Soft & $\begin{array}{l}\text { Ethicon, Johnson \& } \\
\text { Johnson }\end{array}$ \\
\hline & & & & Gynemesh PS & $\begin{array}{l}\text { Ethicon, Johnson \& } \\
\text { Johnson }\end{array}$ \\
\hline & & & & Atrium & Atrium Medical \\
\hline & & & & Marlex & C. R. Bard \\
\hline & & \multirow{4}{*}{ Multifilament } & $\begin{array}{l}\text { Copolymer of } \\
\text { glycolide }(90 \%) \\
\text { and lactide }(10 \%)\end{array}$ & Vicryl & Ethicon, Johnson \&Johnson \\
\hline & & & \multirow{2}{*}{$\begin{array}{l}\text { and lactide }(10 \%) \\
\text { Polypropylene and } \\
\text { polyglecaprone }\end{array}$} & Vypro & $\begin{array}{l}\text { Ethicon, Johnson \& } \\
\text { Johnson }\end{array}$ \\
\hline & & & & UltraPro & $\begin{array}{l}\text { Ethicon, Johnson \& } \\
\text { Johnson }\end{array}$ \\
\hline & & & Polyglycolic acid & Dexon & Davis and Geck \\
\hline \multirow{2}{*}{ II } & \multirow{2}{*}{$\begin{array}{l}\text { Macroporous } \\
<10 \mu \mathrm{m}\end{array}$} & \multirow{2}{*}{ Multifilament } & Expanded PTFF & GORE-TEX & W. L. Gore \\
\hline & & & $\begin{array}{l}\text { Polyethylene } \\
\text { terephthalate }\end{array}$ & Mersuture & $\begin{array}{l}\text { Ethicon, Johnson \& } \\
\text { Johnson }\end{array}$ \\
\hline \multirow{4}{*}{ III } & \multirow{4}{*}{$\begin{array}{l}\text { Macroporous with } \\
\text { microporous } \\
\text { components } \\
<10 \mu \mathrm{m}\end{array}$} & \multirow{4}{*}{ Multifilament } & PTFE & Teflon & C. R. Bard \\
\hline & & & $\begin{array}{l}\text { Polyethylene } \\
\text { terephthalate }\end{array}$ & Mersilene & $\begin{array}{l}\text { Ethicon, Johnson \& } \\
\text { Johnson }\end{array}$ \\
\hline & & & Polypropylene & IVS Tunneller & Tyco Healthcare \\
\hline & & & Woven polyester & Protegen & Boston Scientific \\
\hline \multirow{3}{*}{ IV } & \multirow{3}{*}{$\begin{array}{l}\text { Nanoporous } \\
<1 \mu \mathrm{m}\end{array}$} & \multirow{3}{*}{ Multifilament } & $\begin{array}{l}\text { Silicon-coated } \\
\text { polyester }\end{array}$ & Intermesh & American Medical Systems \\
\hline & & & $\begin{array}{l}\text { Dura mater } \\
\text { substitute }\end{array}$ & $\begin{array}{l}\text { PRECLUDE } \\
\text { MVP Dura } \\
\text { substitute }\end{array}$ & W. L. Gore \\
\hline & & & $\begin{array}{l}\text { Expanded PTFE, } \\
\text { pericardial } \\
\text { membrane } \\
\text { substitute }\end{array}$ & $\begin{array}{l}\text { PRECLUDE } \\
\text { Pericardial } \\
\text { Membrane }\end{array}$ & W. L. Gore \\
\hline
\end{tabular}


TABle 2: Autologous fascia.

\begin{tabular}{|c|c|c|c|}
\hline Author & Sample & Biomechanical properties & Host response \\
\hline $\begin{array}{l}\text { FitzGerald et al., } \\
2000 \text { [23] }\end{array}$ & $\begin{array}{l}\text { Autologous rectus fascia } \\
\text { implanted in } 5 \text { patients suffering } \\
\text { from SUI. Samples obtained, } \\
\text { respectively, from transvaginal } \\
\text { revision after } 3,5,8 \text {, and } 17 \text { weeks } \\
\text { and from replacement after } 4 \\
\text { years. }\end{array}$ & & $\begin{array}{l}\text { (i) Moderate and uniform infiltration } \\
\text { of host fibroblasts and } \\
\text { neovascularization after } 5 \text { and } 8 \text { weeks } \\
\text { of implantation. } \\
\text { (ii) After } 4 \text { years of implantation, no } \\
\text { evidence of inflammatory cell infiltrate } \\
\text { or foreign body reaction and collagen } \\
\text { remodeling by connective tissue } \\
\text { organized longitudinally. }\end{array}$ \\
\hline $\begin{array}{l}\text { Jeong et al., } 2000 \\
{[24]}\end{array}$ & $\begin{array}{l}\text { Autologous lata fascia implanted } \\
\text { in } 16 \text { rabbits randomized into } 4 \\
\text { survival groups and examined } \\
\text { after } 1,2,4 \text {, and } 8 \text { weeks. } \\
\text { Implantation into upper eyelids. }\end{array}$ & & $\begin{array}{l}\text { (i) Low inflammatory cell infiltration. } \\
\text { (ii) Fibroblast infiltration and collagen } \\
\text { remodeling. }\end{array}$ \\
\hline Choe et al., 2001 [21] & $\begin{array}{l}\text { Dermis, rectus fascia, and } \\
\text { vaginal mucosa harvested from } \\
20 \text { women undergoing vagina } \\
\text { prolapse surgery. }\end{array}$ & $\begin{array}{l}\text { Tensiometric analysis of full } \\
\text { strips versus patch suture slings. } \\
\text { Displacement and maximum } \\
\text { load calculated. }\end{array}$ & \\
\hline Kim et al., 2001 [22] & $\begin{array}{l}\text { Autologous rectus fascia } \\
\text { implanted in } 20 \text { rats randomized } \\
\text { into } 2 \text { survival groups ( } 2 \text { and } 4 \\
\text { months). }\end{array}$ & $\begin{array}{l}\text { No significant decrease of the } \\
\text { fracture toughness calculated by } \\
\text { the trouser tear test over } 4 \\
\text { months. }\end{array}$ & \\
\hline
\end{tabular}

Autologous rectus fascia implanted in 15 rabbits randomized into 3 survival groups (2, 6, and 12 weeks). Implantation on the anterior

No significant decrease of biomechanical properties after $12 \quad 50 \%$ decrease in surface area. weeks of implantation. rectus fascia.

\begin{tabular}{|c|c|c|c|}
\hline $\begin{array}{l}\text { Hilger et al., } 2006 \\
\text { [20] }\end{array}$ & $\begin{array}{l}\text { Autologous rectus fascia } \\
\text { implanted in } 20 \text { rabbits } \\
\text { randomized into } 2 \text { survival } \\
\text { groups ( } 6 \text { and } 12 \text { weeks). Half } \\
\text { implanted on the rectus fascia } \\
\text { and half on the posterior vagina } \\
\text { fascia. }\end{array}$ & $\begin{array}{l}\text { No significant decrease of } \\
\text { biomechanical properties after } 12 \\
\text { weeks of implantation. }\end{array}$ & $\begin{array}{l}\text { (i) Collagen remodeling by moderate } \\
\text { collagen infiltration but encapsulation } \\
\text { as well. } \\
\text { (ii) Minimal inflammatory response. } \\
\text { (iii) Minimal neovascularization. }\end{array}$ \\
\hline $\begin{array}{l}\text { Krambeck et al., } \\
2006 \text { [26] }\end{array}$ & $\begin{array}{l}\text { Autologous rectus fascia } \\
\text { implanted subcutaneously on the } \\
\text { anterior rectus fascia of } 10 \text { rabbits } \\
\text { randomized into } 2 \text { survival } \\
\text { groups ( } 6 \text { and } 12 \text { weeks). }\end{array}$ & & $\begin{array}{l}\text { (i) Moderate fibrosis. } \\
\text { (ii) High degree of scarring. } \\
\text { (iii) High degree of inflammatory } \\
\text { infiltrate. }\end{array}$ \\
\hline $\begin{array}{l}\text { de Almeida et al., } \\
2007 \text { [29] }\end{array}$ & $\begin{array}{l}\text { Adult female rats incontinence } \\
\text { model. Marlex, autologous sling, } \\
\text { SIS, polypropylene mesh, and } \\
\text { sham at } 30 \text { and } 60 \text { days. }\end{array}$ & & $\begin{array}{l}\text { Reduced inflammatory response and } \\
\text { collagen production around } \\
\text { autologous grafts, in comparison with } \\
\text { synthetic materials and xenografts. }\end{array}$ \\
\hline $\begin{array}{l}\text { Woodruff et al., } \\
2008 \text { [27] }\end{array}$ & $\begin{array}{l}\text { Autologous fascia grafts } \\
\text { explanted after sling revision } \\
\text { from } 5 \text { women, due to different } \\
\text { complications, between } 2 \text { and } 65 \\
\text { months after implantation. }\end{array}$ & & $\begin{array}{l}\text { (i) Moderate and uniform infiltration } \\
\text { of host fibroblasts and little } \\
\text { neovascularization. } \\
\text { (ii) Collagen remodeling by new } \\
\text { collagen fibers organized } \\
\text { longitudinally. } \\
\text { (iii) No evidence of encapsulation or } \\
\text { gross infection. }\end{array}$ \\
\hline $\begin{array}{l}\text { de Rezende Pinna et } \\
\text { al., } 2011 \text { [28] }\end{array}$ & $\begin{array}{l}\text { Autologous fascia lata implanted } \\
\text { in } 14 \text { rabbits randomized into } 2 \\
\text { survival groups ( } 30 \text { and } 60 \text { days). } \\
\text { Implantation into the right voice } \\
\text { muscle. }\end{array}$ & & $\begin{array}{l}\text { (i) No significant inflammatory } \\
\text { reaction. } \\
\text { (ii) No significant fibrosis or scarring. }\end{array}$ \\
\hline
\end{tabular}


TABLe 3: Allografts.

\begin{tabular}{|c|c|c|c|}
\hline Author & Sample & Biomechanical properties & Host response \\
\hline $\begin{array}{l}\text { Sclafani et al., } 2000 \\
\text { [37] }\end{array}$ & $\begin{array}{l}\text { Human cadaveric dermis (AlloDerm) } \\
\text { disk implanted subdermally behind a } \\
\text { patient's ear. Micronized human } \\
\text { cadaveric dermis (AlloDerm) injected } \\
\text { intradermally and subdermally in } 2 \\
\text { different locations behind a patient's } \\
\text { ear. Both implants were examined } 3 \\
\text { months and } 1 \text { month after } \\
\text { implantation, respectively. }\end{array}$ & & $\begin{array}{l}\text { (i) Both materials extensively invaded by } \\
\text { host fibroblasts. } \\
\text { (ii) Both materials present new collagen } \\
\text { ingrowth. }\end{array}$ \\
\hline $\begin{array}{l}\text { Kim et al., } 2001 \\
{[22]}\end{array}$ & $\begin{array}{l}\text { Human cadaveric fascia implanted in } \\
20 \text { rats randomized into } 2 \text { survival } \\
\text { groups ( } 2 \text { and } 4 \text { months). }\end{array}$ & $\begin{array}{l}\text { No significant decrease of } \\
\text { the fracture toughness } \\
\text { calculated by the trouser } \\
\text { tear test. }\end{array}$ & \\
\hline $\begin{array}{l}\text { Walter et al., } 2003 \\
{[34]}\end{array}$ & $\begin{array}{l}\text { Freeze-dried and gamma-irradiated } \\
\text { human cadaveric lata fascia implanted } \\
\text { in } 18 \text { rabbits and excised } 12 \text { weeks after } \\
\text { implantation. }\end{array}$ & $\begin{array}{l}\text { Significant decrease of } \\
\text { biomechanical properties } \\
\text { after } 12 \text { weeks of } \\
\text { implantation. }\end{array}$ & \\
\hline $\begin{array}{l}\text { Spiess et al., } 2004 \\
{[35]}\end{array}$ & $\begin{array}{l}\text { Human cadaveric fascia lata implanted } \\
\text { subcutaneously on the abdominal wall } \\
\text { of } 20 \text { rats randomized into } 2 \text { survival } \\
\text { groups ( } 6 \text { and } 12 \text { weeks). }\end{array}$ & $\begin{array}{l}\text { No significant decrease of } \\
\text { tensile strength with time. }\end{array}$ & \\
\hline $\begin{array}{l}\text { Yildirim et al., } \\
2005[38]\end{array}$ & $\begin{array}{l}\text { Human cadaveric lata fascia implanted } \\
\text { subcutaneously on the abdominal wall } \\
\text { in } 20 \text { rabbits randomized into } 4 \\
\text { survival groups }(2,7,15 \text {, and } 30 \text { days). }\end{array}$ & & $\begin{array}{l}\text { (i) Acute inflammation by high cell } \\
\text { infiltration predominantly of } \\
\text { polymorphous granulocytes. } \\
\text { (ii) Integration in host tissue by moderate } \\
\text { fibrotic process and muscle infiltration on } \\
\text { day } 30 \text {, with persistent inflammatory } \\
\text { response. }\end{array}$ \\
\hline $\begin{array}{l}\text { Krambeck et al., } \\
2006[26]\end{array}$ & $\begin{array}{l}\text { Cadaveric fascia lata implanted } \\
\text { subcutaneously on the anterior rectus } \\
\text { fascia of } 10 \text { rabbits randomized into } 2 \\
\text { survival groups ( } 6 \text { and } 12 \text { weeks). }\end{array}$ & & $\begin{array}{l}\text { (i) Moderate to high focal fibrosis. } \\
\text { (ii) Minimal to moderate degree of scar. } \\
\text { (iii) High degree of inflammatory } \\
\text { infiltrate. }\end{array}$ \\
\hline $\begin{array}{l}\text { Hilger et al., } 2006 \\
{[20]}\end{array}$ & $\begin{array}{l}\text { Human cadaveric dermis and lata } \\
\text { fascia implanted in } 20 \text { rabbits } \\
\text { randomized into } 2 \text { survival groups ( } 6 \\
\text { and } 12 \text { weeks). Half implanted on the } \\
\text { rectus fascia and half on the posterior } \\
\text { vagina fascia. }\end{array}$ & $\begin{array}{l}\text { Very significant decrease of } \\
\text { biomechanical properties } \\
\text { after } 12 \text { weeks of } \\
\text { implantation. }\end{array}$ & $\begin{array}{l}\text { (i) Two missing or fragmented materials } \\
\text { implanted on the vagina after } 12 \text { weeks. } \\
\text { (ii) Moderate inflammatory response. } \\
\text { (iii) Minimal neovascularization. } \\
\text { (iv) Minimal collagen ingrowth without } \\
\text { significant cell infiltration. }\end{array}$ \\
\hline $\begin{array}{l}\text { Woodruff et al., } \\
2008 \text { [27] }\end{array}$ & $\begin{array}{l}\text { Human cadaveric dermis slings } \\
\text { explanted after revision from } 2 \\
\text { women, due to different complications, } \\
\text { between } 2 \text { and } 65 \text { months after } \\
\text { implantation. }\end{array}$ & & $\begin{array}{l}\text { (i) Moderate levels of encapsulation. } \\
\text { (ii) High levels of degradation. } \\
\text { (iii) Peripheries of the grafts invaded by } \\
\text { fibroblasts but central portions remained } \\
\text { acellular. }\end{array}$ \\
\hline
\end{tabular}

Human cadaveric dermis and fascia lata implanted in 16 rats, respectively, VandeVord et al., and both randomized into 4 survival 2010 [39] groups (2, 4, 8, and 12 weeks). Implantation around the bladder neck, anchored to the surrounding tissues.

Human cadaveric dermis (AlloDerm) Increase of tensile strength implanted in 18 rats randomized into 2 after 30 days and, again, survival groups (30 and 60 days). increase of tensile strength Subcutaneous implantation on after 60 days, respectively, abdominis rectus muscle defect.
Rice et al., 2010

[36] to 30 days. (i) Thin fibrous capsule formation.

(ii) Moderate cell infiltration and angiogenesis.

(i) Moderate amounts of collagen deposition well organized.

(ii) Abundant revascularization. 
TABLE 3: Continued.

\begin{tabular}{|c|c|c|c|}
\hline Author & Sample & Biomechanical properties & Host response \\
\hline $\begin{array}{l}\text { Kolb et al., } 2012 \\
{[40]}\end{array}$ & $\begin{array}{l}\text { Human cadaveric dermis (AlloDerm) } \\
\text { implanted subcutaneously in } 5 \text { pigs } \\
\text { randomized into } 4 \text { survival groups ( } 7 \text {, } \\
21,90 \text {, and } 180 \text { days). }\end{array}$ & & $\begin{array}{l}\text { (i) Robust inflammatory response after } 7 \\
\text { days of implantation, which achieved } \\
\text { maximal level at } 21 \text { days, with formation } \\
\text { of granulomas and areas of necrosis noted } \\
\text { within the graft. } \\
\text { (ii) Moderate fibroblast infiltration, } \\
\text { collagen ingrowth, and } \\
\text { neovascularisation. } \\
\text { (iii) Moderate levels of encapsulation. }\end{array}$ \\
\hline
\end{tabular}

Mersilene was found to induce a higher inflammatory response compared to Prolene, which triggered a minimal inflammatory reaction [89].

Pierce et al. reported a long term study comparing biological and synthetic grafts implanted in rabbits. Polypropylene caused a milder inflammatory reaction with more long term, better host tissue incorporation compared to natural grafts [65]. Also Bazi et al. evaluated biopsies on the basis of inflammatory infiltrate, fibrosis, mast cell presence, muscular infiltration, and collagen filling of the mesh on an arbitrary scale described as low, moderate, or extensive based on $\mathrm{H} \& \mathrm{E}$, periodic acid-Schiff, and toluidine blue staining of tissue. They agreed that all of the materials (Advantage, IVS, SPARC, and TVT) induced inflammation and collagen production, with SPARC being the one with the mildest response and TVT the one with the highest inflammatory response [76]. Elmer et al. reported an increase in macrophages and mast cell counts and a mild but persistent foreign body response to polypropylene meshes [91]. This study is consistent with other reported investigations where the polypropylene meshes are invaded with both macrophages and leukocytes, signs of inflammation, resulting in collagen production $[27,38,65,76$, 83, 85].

In summary the studies agree that polypropylene meshes provoke a fairly pronounced inflammation, leading to a massive cell infiltration into the scaffold and ultimately to collagen production $[27,29,48,76,83,84,86,90-92]$.

\section{Relating Postimplantation Changes to Clinical Outcomes}

4.1. Biomechanics. In general, when biological materials fail this is due to enzymatic degradation after implantation, leading to a loss of mechanical support and weakening of the repair. This appears to apply particularly to the non-crosslinked xenogenic matrices. Chemically cross-linking appears to prevent this degradation and improve the mechanical outcomes. Unfortunately there is a lack of clinical evidence on how these mechanical outcomes translate into patient outcomes. Autologous grafts are the most successful biological material used in contemporary practice and the studies reviewed appear to support the long term mechanical integrity of these grafts. Nevertheless, they present several important limitations that are related to the need to harvest from a donor site. However use of cadaveric tissues avoids these limitations; however their quality depends on the age and comorbidities of the donor and this is maybe the reason for the mixed results in mechanical properties. This is consistent with the available clinical studies which suggest that allografts have poorer cure rates than autologous grafts.

We have found that polypropylene maintains its morphology and strength after implantation for up to 24 weeks $[35,74,76]$. However there was evidence that stiffness increases $[77,93]$. This is consistent with durable cure rates particularly in SUI surgery (there is still some question regarding efficacy of transvaginal POP repair, compared with native tissue repair). The major issue with polypropylene meshes is the associated serious complications, in particular vaginal or urinary tract exposure (up to $10-14 \%$ ). There is some evidence that meshes with greater stiffness cause the surrounding tissue to weaken, an effect termed stress shielding [94]. This can be compared to the effect of metal implants on the surrounding bone after orthopedic surgery. This effect could lead to thinning of the surrounding vaginal tissues as predisposing to erosion.

4.2. Host Response. Biomaterials implanted into the body will always attract the attention of the immune system. With some materials there is an M1 macrophage response of constructive remodeling; this appears to be the case with some biological matrices, SIS in particular. With materials which the body cannot remodel or integrate such as polypropylene meshes, the macrophage response is much more aggressive, an M2 macrophage response $[95,96]$.

It appears that a state of constant inflammation can be generated by some patients in response to some of these nondegradable materials. Constant inflammation leads to an upregulation of degradative enzymes; although these enzymes cannot degrade the material, they may damage the surrounding extracellular matrix and contribute to tissue thinning and mesh exposure. Moreover perpetuation of the inflammatory response can also result in activated fibroblasts, which produce excessive collagen laid down in a disorganized fashion around the implant (i.e., fibrosis), encapsulating the material. A small amount of fibrosis is arguably advantageous to the repair in SUI, providing a stable back stop allowing urethral compression. However excessive fibrosis may lead to mesh contraction resulting in increased pull on the adjacent tissues leading to complications such as voiding dysfunction, pain, and painful intercourse. In POP this excessive fibrotic response can lead to mesh exposure which presents a major reconstructive surgical challenge, often necessitating repeat 
TABLE 4: Xenografts.

\begin{tabular}{|c|c|c|c|}
\hline Author & Sample & Biomechanical properties & Host response \\
\hline $\begin{array}{l}\text { Badylak et al., } \\
2001[52]\end{array}$ & $\begin{array}{l}\text { Abdominal wall defect repaired } \\
\text { with SIS in } 40 \text { dogs randomized } \\
\text { into } 8 \text { survival groups }(1,4,7 \text {, and } \\
10 \text { days and } 1,3,6 \text {, and } 24 \\
\text { months). }\end{array}$ & $\begin{array}{l}\text { Strength was decreased from } \\
\text { day } 1 \text { to day } 10 \text { after } \\
\text { implantation, followed by a } \\
\text { progressive increase, until } \\
\text { reaching double of the } \\
\text { original strength } 24 \text { months } \\
\text { after implantation. }\end{array}$ & $\begin{array}{l}\text { Rapid degradation with associated and } \\
\text { subsequent host remodeling. }\end{array}$ \\
\hline
\end{tabular}

(i) No shrinkage or expansion of the graft site over the 2-year period of the study.

(ii) One week after implantation, abundant

Abdominal wall defect repaired with SIS in 10 dogs and 30 rats, both randomized into 4 survival groups (1 week, 1 month, 3 months, 6 months, and 2 years). levels of polymorphonuclear leukocytes diminished to negligible after 1 month.

(iii) Moderate neovascularization.

(iv) By 3 months, graft material was not recognizable and was replaced by moderately well-organized host tissues including collagenous connective tissue, adipose tissue, and skeletal muscle.

(i) Completely intact acellular sling.

(ii) Well defined fibrous capsule.

(iii) Chronic inflammatory response. months after pubovaginal implantation of the sling due to severe obstruction.

$\begin{array}{ll}\text { [60] } & \begin{array}{l}\text { pubovaginal implantation of the } \\ \text { sling due to severe obstruction. }\end{array}\end{array}$

Zhang et al., 2003 SIS implanted in the abdominal [51] wall of rats for up to 2 months.

Biopsies taken from the implantation site of the SIS band under the vaginal mucosa from 3

Wiedemann and patients during reoperation, at a Otto, 2004 [56] mean of 12.7 months, after pubourethral sling procedures due to recurrent urinary stress incontinence.

Abdominal wall defect repaired Konstantinovic et with SIS in 24 Wistar rats al., 2005 [50] randomized into 4 survival groups (7, 14, 30, and 90 days).

Significant increase of biomechanical properties after 90 days of implantation.
SIS together with the abdominal wall has increased strength.
Levels of interleukin 2 and interleukin 6 were high straight after the operation but they become normal after 2 months. (i) Focal residues of SIS implant.

(ii) No evidence of a specific tissue reaction that might point to a foreign body reaction. (iii) No evidence of any significant immunological reaction and in particular no

(i) Moderate acute inflammatory response at day 7 , decreased to minimal after 90 days.

(ii) Moderate neovascularization.

(iii) Abundant collagen deposition well evidence of any chronic inflammatory reaction. organized after 90 days.

For both grafts:

(i) absent acute inflammatory response,

(ii) from moderate chronic inflammation after 1 week of implantation to minimal after 20 weeks,

(iii) absent eosinophilic infiltration and stromal fibroblastic reaction over the entire implantation,

(iv) from moderate fibrosis and vascularity around the grafts after 1 week of implantation to minimal after 20 weeks.

\begin{tabular}{lll}
\hline $\begin{array}{l}\text { Poulose et al., } \\
2005 \text { [57] }\end{array}$ & $\begin{array}{l}\text { 12 female pigs were implanted } \\
\text { with SIS intraperitoneally for up } \\
\text { to 6 weeks. }\end{array}$ & $\begin{array}{l}\text { (i) Cell infiltration. } \\
\text { (ii) Vascularization. } \\
\text { (iii) Collagen deposition and remodelling. }\end{array}$ \\
\hline \multirow{2}{*}{$\begin{array}{l}\text { Thiel et al., 2005 implanted subcutaneously on } \\
\text { [58] }\end{array}$} & $\begin{array}{l}\text { the abdominal wall of 30 rats } \\
\text { randomized into 3 survival } \\
\text { groups (7,30, and 90 days). }\end{array}$ & $\begin{array}{l}\text { (i) Moderate inflammatory reaction increased } \\
\text { to severe after } 90 \text { days. }\end{array}$ \\
\end{tabular}


TABLe 4: Continued.

\begin{tabular}{|c|c|c|c|}
\hline Author & Sample & Biomechanical properties & Host response \\
\hline $\begin{array}{l}\text { Krambeck et al., } \\
2006 \text { [26] }\end{array}$ & $\begin{array}{l}\text { SIS and porcine dermis } \\
\text { implanted subcutaneously on the } \\
\text { anterior rectus fascia of } 10 \text { rabbits } \\
\text { randomized into } 2 \text { survival } \\
\text { groups ( } 6 \text { and } 12 \text { weeks). }\end{array}$ & & $\begin{array}{l}\text { (i) Porcine dermis presented moderate fibrosis } \\
\text { which was minimal for SIS. } \\
\text { (ii) Minimal degree of scar for both grafts and } \\
\text { high degree of inflammatory infiltrate. }\end{array}$ \\
\hline $\begin{array}{l}\text { Ko et al., } 2006 \\
{[54]}\end{array}$ & $\begin{array}{l}\text { Abdominal wall defect repaired } \\
\text { with } 8 \text {-layer SIS in } 20 \text { domestic } \\
\text { pigs randomized into } 2 \text { survival } \\
\text { groups ( } 1 \text { and } 4 \text { months). }\end{array}$ & $\begin{array}{l}\text { No significant changes of } \\
\text { biomechanical properties after } \\
4 \text { months of implantation. }\end{array}$ & $\begin{array}{l}\text { (i) Dense fibrous connective tissue ingrowth. } \\
\text { (ii) Minimal to mild mononuclear } \\
\text { inflammatory cell infiltrate throughout the } \\
\text { connective tissue. }\end{array}$ \\
\hline $\begin{array}{l}\text { Hilger et al., } 2006 \\
\text { [20] }\end{array}$ & $\begin{array}{l}\text { Porcine dermis implanted in } 20 \\
\text { rabbits randomized into } 2 \\
\text { survival groups ( } 6 \text { and } 12 \text { weeks). } \\
\text { Half implanted on the rectus } \\
\text { fascia and half on the posterior } \\
\text { vagina fascia. }\end{array}$ & $\begin{array}{l}\text { Very significant decrease of } \\
\text { biomechanical properties after } \\
12 \text { weeks of implantation. }\end{array}$ & $\begin{array}{l}\text { (i) Two missing or fragmented materials } 12 \\
\text { weeks after being implanted on the vagina. } \\
\text { (ii) Moderate to strong inflammatory response. } \\
\text { (iii) Minimal collagen ingrowth without } \\
\text { significant cell infiltration. } \\
\text { (iv) Minimal neovascularization. }\end{array}$ \\
\hline $\begin{array}{l}\text { Kim et al., } 2007 \\
\text { [59] }\end{array}$ & $\begin{array}{l}\text { SIS implanted in the } \\
\text { subcutaneous dorsum of } 3 \text { rats } \\
\text { sacrificed after } 2 \text { weeks. }\end{array}$ & & $\begin{array}{l}\text { (i) Prominent infiltration and ingrowth of host } \\
\text { cells. } \\
\text { (ii) Few macrophages infiltrated or } \\
\text { accumulated around the grafts. }\end{array}$ \\
\hline
\end{tabular}

(i) $80 \%$ of contraction from original surface

SIS implanted on the peritoneal

Rauth et al., 2007 surface of the abdominal wall of

[63] 6 pigs sacrificed 8 weeks after implantation. area.

(ii) Moderate neovascularization.

(iii) Densely populated by host cells with moderate amounts of new disorganized collagen deposition.

(i) Severe encapsulation.

(ii) No degradation.

(iii) No fibroblasts infiltration and neovascularization.

(i) Considerable contraction after 1 month for both materials, but not significant change over the next 5 months.

(ii) Better integration of both materials at late stage by scar formation.

Abdominal wall defect repaired with SIS and cross-linked porcine dermis (Permacol) in 33 primates randomized into 3 survival groups (1, 3, and 6 months). (iii) Inflammatory cells infiltration 3 months after implantation for SIS associated with formation of few blood vessels.

(iv) Acellular porcine dermis over the entire course implantation with substantial inflammation surrounding their perimeter.

(v) Partial resorption for both materials after 6 months.

11 grafts remained intact without significant changes of biomechanical properties compared to the baseline

Cross-linked porcine dermis

Pierce et al., 2009 [65] implanted on the abdominal wall and posterior vagina of 18 rabbits sacrificed 9 months after implantation. values. They were just thicker and tolerated with less elongation at failure. Seven grafts were partially degraded but thicker again and with significant decrease of all biomechanical properties. (i) Host connective tissue incorporation between fibers.

(ii) Intense foreign body reaction in degraded grafts. 
TABLE 4: Continued.

\begin{tabular}{|c|c|c|c|}
\hline Author & Sample & Biomechanical properties & Host response \\
\hline $\begin{array}{l}\text { VandeVord et al., } \\
2010 \text { [39] }\end{array}$ & $\begin{array}{l}\text { SIS and porcine dermis } \\
\text { implanted in } 16 \text { rats, respectively, } \\
\text { and both randomized into } 4 \\
\text { survival groups }(2,4,8 \text {, and } 12 \\
\text { weeks). Implantation around the } \\
\text { bladder neck, anchored to the } \\
\text { surrounding tissues. }\end{array}$ & & $\begin{array}{l}\text { (i) Thin fibrous capsule formation. } \\
\text { (ii) Moderate cell infiltration and angiogenesis } \\
\text { for SIS and minimal for porcine dermis. }\end{array}$ \\
\hline $\begin{array}{l}\text { Rice et al., } 2010 \\
\text { [36] }\end{array}$ & $\begin{array}{l}\text { Abdominal wall defect repair } \\
\text { with SIS (Surgisis) in } 18 \text { rats } \\
\text { randomized into } 2 \text { survival } \\
\text { groups ( } 30 \text { and } 60 \text { days). }\end{array}$ & $\begin{array}{l}\text { Increase of tensile strength } \\
\text { after } 30 \text { days and, increase of } \\
\text { tensile strength after } 60 \text { days, } \\
\text { respectively, to } 30 \text { days. }\end{array}$ & $\begin{array}{l}\text { (i) Moderate amounts of collagen deposition } \\
\text { well organized. } \\
\text { (ii) Abundant revascularization. }\end{array}$ \\
\hline
\end{tabular}

(i) Pelvicol presented high degradation rates associated with no foreign body reaction.

13 patients underwent secondary sacrocolpopexy because of a graft

Deprest et al., 2010 [61]

$$
\text { related complication after the }
$$
initial sacrocolpopexy with porcine dermal collagen (Pelvicol) (9) or SIS (Surgisis) (4).

(ii) Pelvicol remnants were integrated into collagen rich connective tissue with limited neovascularization (scar host tissue).

(iii) No significant body foreign reaction to Surgisis grafts.

(iv) Surgisis no longer recognizable replaced by irregularly organized connective tissue and fat tissue.

(i) Pronounced inflammatory response 1 to 4 weeks after implantation for SIS compared with porcine dermis, but falling to similar negligible values for both after 12 weeks.

Abdominal wall defect repaired with SIS and acellular porcine

Liu et al., 2011

[49] dermal matrix in 50 Sprague Dawley rats randomized into 5 survival groups $(1,2,4,8$, and 12 weeks).
After initial decrease of biomechanical properties at week 2 , these were increased over the next 10 weeks reaching similar values to week 1 . (ii) Large neovascularization and collagen deposition, which was higher for SIS group. (iii) SIS implants degraded more quickly and were almost totally replaced by organized collagenous tissues.

(iv) Contraction at the first weeks leading to significant lower surface area in both materials.

(i) Moderate cell infiltration.

(ii) Moderate extracellular matrix deposition.

(iii) Moderate neovascularisation.

(iv) Partial degradation and from widely to mild fibrous encapsulation.

(i) Mild inflammatory response decreased to minimal from day 7 to day 180 after implantation.

Cross-linked porcine dermis (Permacol) implanted subcutaneously in 5 pigs randomized into 4 survival groups (7, 21, 90, and 180 days).
Significantly greater incorporation strengths after 6 month. into 2 survival groups ( 1 and 6 months).
Kolb et al., 2012

[40] (ii) None to minimal neovascularization after 180 days.

(iii) Small amount of residual SIS remained surrounded by mild to moderate chronic inflammation.

(iv) Moderate levels of encapsulation.

(i) Cell infiltrates into all grafts by day 35 .

(ii) Degradation of the scaffold most pronounced at the periphery with fibrous tissue, angiogenesis, and foreign body giant cells noted.

(iii) Grafts surrounded by a dense and circumferentially organized connective tissue. (iv) Mononuclear cells decreased in number compared with earlier time points. 
TABLE 5: Polypropylene meshes.

\begin{tabular}{|c|c|c|c|}
\hline Author & Sample & Biomechanical properties & Host response \\
\hline $\begin{array}{l}\text { Falconer et al., } \\
2001[89]\end{array}$ & $\begin{array}{l}16 \text { women were implanted with TVT for } \\
\text { up to } 2 \text { years: } 6 \text { with Mersilene and } 10 \\
\text { with Prolene. }\end{array}$ & & $\begin{array}{l}\text { Mersilene induces higher inflammatory } \\
\text { response than Prolene. Mersilene is easier } \\
\text { to extract than Prolene. }\end{array}$ \\
\hline $\begin{array}{l}\text { Klinge et al., } \\
2002[80]\end{array}$ & $\begin{array}{l}\text { Heavy weight monofilament with small } \\
\text { pore size (HWM) and low weight with } \\
\text { large pore size multifilament (LWM) on } \\
\text { the posterior abdominal wall of rats for } \\
7,14,21 \text {, and } 90 \text { days. }\end{array}$ & & $\begin{array}{l}\text { (i) HWM: intense inflammation, } \\
\text { embedded in connective tissue. } \\
\text { (ii) LWM: less pronounced inflammatory } \\
\text { response and fibrotic capsule, with } \\
\text { collagen distributed within the mesh. }\end{array}$ \\
\hline $\begin{array}{l}\text { Wang et al., } \\
2004[90]\end{array}$ & $\begin{array}{l}17 \text { women with sling erosion and } 7 \\
\text { women with voiding difficulties } \\
\text { implanted with TVT and SPARC. }\end{array}$ & & $\begin{array}{l}\text { Pronounced fibrosis around the } \\
\text { fibers-erosion and voiding difficulty as a } \\
\text { result. }\end{array}$ \\
\hline $\begin{array}{l}\text { Rabah et al., } \\
2004[84]\end{array}$ & $\begin{array}{l}\text { Implantation of Surgipro and cadaveric } \\
\text { fascia lata in rabbit's bladder neck for } 6 \\
\text { and } 12 \text { weeks. }\end{array}$ & & $\begin{array}{l}\text { (i) Cadaveric fascia lata group: the } \\
\text { implant was incorporated in a plate of } \\
\text { fibrous tissue. } \\
\text { (ii) Polypropylene mesh: inflammation } \\
\text { localized on the graft. }\end{array}$ \\
\hline $\begin{array}{l}\text { Spiess et al., } \\
2004[35]\end{array}$ & $\begin{array}{l}\text { TVT and cadaveric fascia lata implanted } \\
\text { in abdominal wall of rats for } 6 \text { and } 12 \\
\text { weeks. }\end{array}$ & $\begin{array}{l}\text { TVT has the greater break } \\
\text { load and the maximum } \\
\text { average load compared to } \\
\text { cadaveric fascia lata. }\end{array}$ & \\
\hline $\begin{array}{l}\text { Zheng et al., } \\
2004[81]\end{array}$ & $\begin{array}{l}\text { Prolene and Pelvicol implanted in full } \\
\text { thickness abdominal wall defects in rats } \\
\text { for } 7,14,30 \text {, and } 90 \text { days. }\end{array}$ & & $\begin{array}{l}\text { Prolene prosthesis shows the presence of } \\
\text { leukocytes in the activated state. }\end{array}$ \\
\hline $\begin{array}{l}\text { Konstantinovic } \\
\text { et al., } 2005[50]\end{array}$ & $\begin{array}{l}\text { Marlex and non-cross-linked Surgisis } \\
\text { implanted on the anterior abdominal } \\
\text { wall of rats for } 7,14,30 \text {, and } 90 \text { days. }\end{array}$ & & $\begin{array}{l}\text { (i) Marlex: more pronounced } \\
\text { inflammatory reaction and } \\
\text { vascularization throughout the graft than } \\
\text { Surgisis } \\
\text { (ii) Surgisis: milder inflammatory } \\
\text { reaction. }\end{array}$ \\
\hline $\begin{array}{l}\text { Yildirim et al., } \\
2005[38]\end{array}$ & $\begin{array}{l}\text { Gynecare TVT, SPARC, polypropylene } \\
\text { mesh, and IVS implanted in contact } \\
\text { with the rats rectus muscle for up to } 30 \\
\text { days. }\end{array}$ & & $\begin{array}{l}\text { Inflammation and fibrosis are decreased } \\
\text { in large pore meshes. }\end{array}$ \\
\hline $\begin{array}{l}\text { Thiel et al., } 2005 \\
\text { [58] }\end{array}$ & $\begin{array}{l}\text { Monofilament polypropylene mesh, } \\
\text { silicone mesh, SIS, and PLA were } \\
\text { implanted subcutaneously on the } \\
\text { abdomen of rats for } 7,30 \text {, and } 90 \text { days. }\end{array}$ & & $\begin{array}{l}\text { Polypropylene induces the mildest } \\
\text { inflammatory response among the } \\
\text { samples. }\end{array}$ \\
\hline $\begin{array}{l}\text { Bogusiewicz et } \\
\text { al., } 2006[83]\end{array}$ & $\begin{array}{l}\text { Monofilament TVT and multifilament } \\
\text { IVS were implanted in rats rectus fascia } \\
\text { for } 42 \text { days. }\end{array}$ & & $\begin{array}{l}\text { (i) They induce production of similar } \\
\text { amount of collagen. } \\
\text { (ii) Differences in the arrangement of } \\
\text { collagen and inflammation intensity. }\end{array}$ \\
\hline $\begin{array}{l}\text { Boulanger et al., } \\
2006 \text { [87] }\end{array}$ & $\begin{array}{l}\text { Vicryl, Vypro, Prolene, Prolene Soft, and } \\
\text { Mersuture were implanted in pigs } \\
\text { peritoneum for } 10 \text { weeks. }\end{array}$ & & $\begin{array}{l}\text { (i) Vicryl: low level of inflammation and } \\
\text { completely absorbed. } \\
\text { (ii) Vypro: intense inflammation and } \\
\text { strong fibrotic response. } \\
\text { (iii) Prolene and Prolene Soft: well } \\
\text { integrated, weak inflammatory response. } \\
\text { (iv) Mersuture: no good integration. }\end{array}$ \\
\hline $\begin{array}{l}\text { Krambeck et al., } \\
2006[26]\end{array}$ & $\begin{array}{l}\text { SPARC mesh, human cadaveric fascia, } \\
\text { porcine dermis, SIS, and autologous } \\
\text { fascia were implanted in rabbits rectus } \\
\text { fascia for } 12 \text { weeks. }\end{array}$ & & $\begin{array}{l}\text { (i) Polypropylene mesh has the greatest } \\
\text { scar formation. } \\
\text { (ii) Polypropylene has the mildest } \\
\text { inflammatory response. }\end{array}$ \\
\hline $\begin{array}{l}\text { Boukerrou et al., } \\
2007 \text { [75] }\end{array}$ & $\begin{array}{l}\text { Preperitoneal implantation of Vicryl, } \\
\text { Vypro, Prolene, Prolene Soft, and } \\
\text { Mersuture mesh for } 2 \text { months in pigs. }\end{array}$ & $\begin{array}{l}\text { Nonabsorbable, } \\
\text { monofilamentous, } \\
\text { macroporous materials } \\
\text { (type I) seem more } \\
\text { resistant, retract less, and } \\
\text { have the best tolerance. }\end{array}$ & $\cdot$ \\
\hline
\end{tabular}


TABLE 5: Continued.

\begin{tabular}{llll}
\hline Author & Sample & Biomechanical properties & Host response \\
\hline $\begin{array}{l}\text { Spelzini et al., } \\
2007 \text { [82] }\end{array}$ & $\begin{array}{l}\text { Polypropylene type I mesh and } \\
\text { macroporous silk construct were } \\
\text { implanted in rat fascial defects for 7, 14, } \\
\text { 30, and 90 days. }\end{array}$ & $\begin{array}{l}\text { Polypropylene meshes induce a moderate } \\
\text { inflammatory response and not } \\
\text { architectural degradation. }\end{array}$ \\
\hline $\begin{array}{l}\text { Zorn et al., 2007 } \\
\text { [74] }\end{array}$ & $\begin{array}{l}\text { Rat abdominal wall was implanted with } \\
\text { SPARC, TVT, and SIS for 6 weeks and 9, } \\
\text { 6, 9, and 12 months. }\end{array}$ & $\begin{array}{l}\text { TVT has tensile } \\
\text { properties similar to } \\
\text { SPARC and they are } \\
\text { superior to Stratasis. }\end{array}$ & \\
\hline $\begin{array}{l}\text { Bazi et al., 2007 } \\
\text { [76] }\end{array}$ & $\begin{array}{l}\text { Rats rectus fascia was implanted with } \\
\text { Advantage, IVS, SPARC, and TVT for } \\
\text { up to 24 weeks. }\end{array}$ & $\begin{array}{l}\text { They all show similar } \\
\text { mechanical properties } \\
\text { after removal. }\end{array}$ & $\begin{array}{l}\text { They induce different host responses due } \\
\text { to different porosity. }\end{array}$ \\
\hline
\end{tabular}

$\begin{array}{ll}\text { Tayrac et al., } & \begin{array}{l}\text { Ewes vaginas were implanted with a } \\ \text { noncoated LW polypropylene mesh } \\ \text { (Soft Prolene) and a coated one } \\ \text { (Ugytex) from } 1 \text { to } 12 \text { weeks. }\end{array}\end{array}$

\begin{tabular}{|c|c|c|}
\hline & Rabbits vaginas were implanted with & \\
\hline Huffaker et al., & Pelvitex (collagen-coated) and & Both materials induce a mild foreign \\
\hline $2008[86]$ & $\begin{array}{l}\text { Gynemesh (uncoated polypropylene } \\
\text { meshes) for up to } 12 \text { weeks. }\end{array}$ & body reaction with minimal fibrosis. \\
\hline
\end{tabular}

24 grafts were explanted in women

Woodruff et al., undergoing sling revision after 2-34

2008 [27] months. Grafts were polypropylene meshes, autologous fascia, porcine dermis, and cadaveric dermis.

$\begin{array}{ll}\text { Elmer et al., } & \text { Prolift was implanted in humans for } 1 \\ 2009 \text { [91] } & \text { year. }\end{array}$ 2009 [91] year.

\begin{tabular}{ll}
\hline $\begin{array}{l}\text { Pierce et al., } \\
\text { 2009 [65] }\end{array}$ & $\begin{array}{l}\text { Polypropylene mesh versus cross-linked } \\
\text { porcine dermis implanted in rabbits } \\
\text { vagina and abdomen for 9 months. }\end{array}$ \\
\hline $\begin{array}{l}\text { Melman et al., } \\
\text { 2011 [77] }\end{array}$ & $\begin{array}{l}\text { Bard mesh (HWPP), Ultrapro (LWPP), } \\
\text { and GORE INFINIT Mesh (ePTFE) in } \\
\text { minipigs hernia repair for 1, 3, and 5 } \\
\text { months. }\end{array}$ \\
\hline & $\begin{array}{l}\text { Surgipro, Optilene, and GORE INFINIT } \\
\text { Mesh (ePTFE) were implanted in rabbits } \\
\text { abdominal wall defect for 14 days. }\end{array}$
\end{tabular}

\begin{tabular}{ll}
\hline & \\
& $\begin{array}{l}\text { Gynemesh in two sizes }(50 \times 50 \mathrm{~mm} \text { and } \\
35 \times 35 \mathrm{~mm}) \text { implanted in } 20 \text { adult ewes }\end{array}$ \\
Manodoro et al., & $\begin{array}{l}35013 \text { [78 } 60 \text { and } 90 \text { days, both on the } \\
\text { abdominal and vaginal walls. }\end{array}$
\end{tabular}

HWPP: heavy weight polypropylene.

LWPP: lightweight polypropylene (also called soft); ePTFE: expanded polytetrafluoroethylene; PLGA: polylactide-co-glycolide acid; PLA: polylactide acid; PGA: polyglycolide acid.

Similar inflammatory response between the two materials.

No evidence of degradation or encapsulation, abundant host infiltration. Neovascularisation was visible.

(i) Increase in macrophages and mast cells count.

(ii) Mild but persistent foreign body response.

Polypropylene caused milder inflammatory reaction, more long term, good host tissue incorporation.
Their maximum tensile strength decreases for all of them. (i) Inflammation decreases with time.

(ii) Cell infiltration increases with time. (i) PTFE induces an increased

LWPP implants might be improved by the newly formed tissue around it. macrophage response when compared to polypropylene.

(ii) Increase in collagen deposition in high porosity meshes.
Implants were contracting more when implanted on the vaginal wall, compared to abdominal wall.

Grafts implanted on the vaginal wall are stiffer than the ones implanted on the abdominal wall, after retrieval. (i) $30 \%$ of the $50 \times 50$ meshes caused vaginal erosion and exposure.

(ii) $60 \%$ of the $35 \times 35$ meshes had reduced surface (i.e., contracting after 90 days.) 
procedures with no guarantee of symptom resolution. Nevertheless with the observation that the vast majority of patients do well with mesh, it can be concluded that some degree of fibrosis is helpful to the surgical management whereas clearly excessive fibrosis is detrimental.

Implantation of autologous fascia in general showed good integration within host tissues, associated with a low inflammatory response, compared to polypropylene meshes and degree of graft remodelling in the available human studies $[50,84]$. It must be borne in mind that the human studies were all reoperative cases for clinical failure. It is difficult to speculate on whether all successful outcomes result in fully integrated and remodelled graft. Non-cross-linked xenografts are associated with clinical failure due to rapid degradation which is presumably too soon for the regeneration of strong tissues in its place $[20,24,29]$. The cross-linked grafts avoid this but rather similar to the synthetic mesh are associated with a perpetuated inflammatory response as the body is unable to integrate and remodel them. This ultimately leads to encapsulation of the graft. It would therefore seem appropriate that there should be a proper balance of degradation and replacement by new host tissue with xenografts. SIS appears to fulfill this.

This relationship between grafts and host tissues will vary for different materials and with different individuals. Here it is worth noting that as many as $15 \%$ of the population are allergic to nickel and more than $80 \%$ can become sensitized to nickel on sustained exposure [97] and that there are very successful studies involving muscle regeneration using decellularized ECM [98]. Therefore, it is clear that the immune response to any foreign material is complex, dynamic, and patient specific. The fact that polypropylene meshes provoke little adverse reaction when implanted in the abdominal wall for hernia repair but are associated with complications in the pelvic floor may also suggest a site-specific host response notwithstanding the differences in biomechanical aspects [99]. This contrasting response has been confirmed in ewes [78], therefore the need for relevant animal models for longer studies [100].

\section{Perspective on the Ideal Material}

Whilst authors have previously described paradigms of the ideal material, we suggest that these have been unrealistic [101]. Ultimately a permanent material will always cause complications in some patients due to variation in individual immune responses. Conversely degradable materials will fail in some patients. The question is which is least desirable? Whilst recurrent symptoms can always be treated by corrective surgery, the complications of polypropylene mesh such as chronic pain have proven resistant to treatment in many cases. Thus we suggest that materials for this application should be degradable based on the principle of least harm. With this in mind, it is essential that the degradability is tuned so that it allows enough time for the development of a neotissue that is able to mechanically support the pelvic organs. A material that does not cause any inflammation is unrealistic and probably undesirable as an initial inflammatory response is required to promote angiogenesis and collagen ingrowth, integrating the material. This is essentially an M1 macrophage response. For this to happen, the material should be readily permeable to host cells. On a practical level any material for this application needs to be robust to withstand surgical handling and provide support at the point of insertion. We suggest that a more realistic material for this application would be the one that

(i) is degradable,

(ii) provokes an acute inflammatory response,

(iii) undergoes tissue remodeling,

(iv) is permeable to cells,

(v) is mechanically robust at point of implantation.

\section{Conclusion and Future Perspective}

The clinical experience suggests that both synthetic and biological materials can provide successful outcomes when used in the surgical management of pelvic floor disorders. However, it has become clear that there is an incidence of significant complications of polypropylene meshes and that many surgeons do not consider the complication rate acceptable. Both the host response and the mechanical properties of the materials need to be taken into consideration to predict success of the implants, in addition to their response to dynamic loading. There has clearly been a lack of adequate preclinical evaluation with polypropylene mesh and we suggest several steps which may make the development for new materials an altogether safer endeavor:

(i) a better understanding of the forces within the pelvic floor, whose materials need to cope with when implanted;

(ii) computational modeling of how materials might perform under load for many years (this can be achieved using in virtuo models once established);

(iii) the investigation of immune responses in patients in whom materials perform well over many years versus patients in whom they cause severe complications (using biochemical markers, genomic markers, and non-invasive imaging);

(iv) the development of better animal models that develop the complications associated with vaginal mesh use such as exposure;

(v) establishment of standardized criteria to evaluate the performance of materials in in vivo and in vitro studies so that they can be accurately compared.

There are several other factors which require urgent attention but are beyond the scope of this review. Surgical expertise based on training and experience in reconstructive surgery is a key factor in outcomes of pelvic floor procedures and there is a need to ensure that surgeons are adequately trained. Patient specific issues, such as individual anatomy and tissue strength, could also impact outcomes and further investigation remains necessary to assess these aspects and their role in determining outcome [102]. Although databases 
to track complication rates exist, such as MAUDE and Postmarket Surveillance Studies, the medical community needs to participate more fully in these databases in order to more critically audit patient outcomes and move forward.

Ultimately to develop new effective and safe materials there is a need for a multidisciplinary approach that combines the efforts of those working in regenerative medicine, biomaterials, and surgery.

\section{Disclosure}

Professor Chris Chapple is a consultant for AMS, Allergan, Astellas, Lilly, ONO, Pfizer, and Recordati. He is also a researcher, speaker, and trial participant for Allergan, Astellas, Pfizer, and Recordati. All the other authors have nothing to disclose.

\section{Conflict of Interests}

The authors declare that there is no conflict of interests regarding the publication of this paper.

\section{Acknowledgment}

The authors gratefully acknowledge support for this work. Mrs Gigliobianco was supported by an EPSRC Doctoral Training College PhD and Dr. Roman Regueros was supported by the Trust European Marie Curie Network. The authors also would like to thank Emma Gugon for Figure 1.

\section{References}

[1] I. Milsom, D. Altman, R. Cartwright et al., "Epidemiology of urinary incontinence (UI) and other lower urinary tract symptoms (LUTS), pelvic organ prolapse (POP) and anal incontinence," in Incontinence (5th International Consultation on Incontinence), P. Abrams, L. Cardozo, S. Khoury, and A. Wein, Eds., Paris, France, 2013.

[2] P. Abrams, L. Cardozo, M. Fall et al., "The standardisation of terminology of lower urinary tract function: report from the standardisation sub-committee of the International Continence Society," Neurourology and Urodynamics, vol. 21, no. 2, pp. 167178, 2002.

[3] X. Fritel, N. Varnoux, M. Zins, G. Breart, and V. Ringa, "Symptomatic pelvic organ prolapse at midlife, quality of life, and risk factors," Obstetrics and Gynecology, vol. 113, no. 3, pp. 609-616, 2009.

[4] B. T. Haylen, D. de Ridder, R. M. Freeman et al., "An International Urogynecological Association (IUGA)/International Continence Society (ICS) joint report on the terminology for female pelvic floor dysfunction," Neurourology and Urodynamics, vol. 29, no. 1, pp. 4-20, 2010.

[5] S. Maggi, N. Minicuci, J. Langlois, M. Pavan, G. Enzi, and G. Crepaldi, "Prevalence rate of urinary incontinence in community-dwelling elderly individuals: The Veneto study," Journals of Gerontology Series A: Biological Sciences and Medical Sciences, vol. 56, no. 1, pp. M14-M18, 2001.

[6] A. Miedel, G. Tegerstedt, M. Mæhle-Schmidt, O. Nyrén, and M. Hammarström, "Nonobstetric risk factors for symptomatic pelvic organ prolapse," Obstetrics and Gynecology, vol. 113, no. 5, pp. 1089-1097, 2009.
[7] I. Nygaard, C. Bradley, and D. Brandt, "Pelvic organ prolapse in older women: prevalence and risk factors," Obstetrics and Gynecology, vol. 104, no. 3, pp. 489-497, 2004.

[8] U. Ulmsten and P. Petros, "Intravaginal slingplasty (IVS): an ambulatory surgical procedure for treatment of female urinary incontinence," Scandinavian Journal of Urology and Nephrology, vol. 29, no. 1, pp. 75-82, 1995.

[9] K. Ward and P. Hilton, "Prospective multicentre randomised trial of tension-free vaginal tape and colposuspension as primary treatment for stress incontinence," British Medical Journal, vol. 325, no. 7355, pp. 67-70, 2002.

[10] J. Mahon, D. Varley, and J. Glanville, "Summaries of the safety/adverse effects of vaginal tapes/slings/meshes for stress urinary incontinence and prolapse," Medicines and Healthcare products Regulatory Agency, 2012.

[11] D. G. Schultz, FDA Public Health Notification: Serious Complications Associated with Transvaginal Placement of Surgical Mesh in Repair of Pelvic Organ Prolapse and Stress Urinary Incontinence, 2008.

[12] US-FDA, Safety Communication: UPDATE on Serious Complications Associated with Transvaginal Placement of Surgical Mesh for Pelvic Organ Prolapse, US Food and Drug Administration (FDA), Silver Spring, Md, USA, 2011.

[13] C. Birch and M. M. Fynes, "The role of synthetic and biological prostheses in reconstructive pelvic floor surgery," Current Opinion in Obstetrics \& Gynecology, vol. 14, no. 5, pp. 527-535, 2002.

[14] D. O. Freytes, R. S. Tullius, and S. F. Badylak, "Effect of storage upon material properties of lyophilized porcine extracellular matrix derived from the urinary bladder," Journal of Biomedical Materials Research Part B: Applied Biomaterials, vol. 78, no. 2, pp. 327-333, 2006.

[15] C. T. Vangsness Jr., I. A. Garcia, C. R. Mills, M. A. Kainer, M. R. Roberts, and T. M. Moore, "Allograft transplantation in the knee: tissue regulation, procurement, processing, and sterilization," The American Journal of Sports Medicine, vol. 31, no. 3, pp. 474-481, 2003.

[16] J. Golomb, A. Groutz, Y. Mor, I. Leibovitch, and J. Ramon, "Management of urethral erosion caused by a pubovaginal fascial sling," Urology, vol. 57, no. 1, pp. 159-160, 2001.

[17] T. O. Morgan Jr., O. L. Westney, and E. J. McGuire, "Pubovaginal sling: 4-year outcome analysis and quality of life assessment," Journal of Urology, vol. 163, no. 6, pp. 1845-1848, 2000.

[18] J. M. Latini, M. M. Lux, and K. J. Kreder, "Efficacy and morbidity of autologous fascia lata sling cystourethropexy," Journal of Urology, vol. 171, no. 3, pp. 1180-1184, 2004.

[19] C. D. Dora, D. S. Dimarco, M. E. Zobitz, and D. S. Elliott, “Time dependent variations in biomechanical properties of cadaveric fascia, porcine dermis, porcine small intestine submucosa, polypropylene mesh and autologous fascia in the rabbit model: implications for sling surgery," Journal of Urology, vol. 171, no. 5, pp. 1970-1973, 2004.

[20] W. S. Hilger, A. Walter, M. E. Zobitz, K. O. Leslie, P. Magtibay, and J. Cornella, "Histological and biomechanical evaluation of implanted graft materials in a rabbit vaginal and abdominal model," American Journal of Obstetrics and Gynecology, vol. 195, no. 6, pp. 1826-1831, 2006.

[21] J. M. Choe, R. Kothandapani, L. James, and D. Bowling, "Autologous, cadaveric, and synthetic materials used in sling surgery: comparative biomechanical analysis," Urology, vol. 58, no. 3, pp. $482-486,2001$. 
22] H. L. Kim, M. C. LaBarbera, R. V. Patel, W. J. Cromie, and G. T. Bales, "Comparison of the durability of cadaveric and autologous fascia using an in vivo model," Urology, vol. 58, no. 5, pp. 800-804, 2001.

[23] M. P. FitzGerald, J. Mollenhauer, and L. Brubaker, "The fate of rectus fascia suburethral slings," The American Journal of Obstetrics and Gynecology, vol. 183, no. 4, pp. 964-966, 2000.

[24] S. Jeong, Y. R. Ma, and Y. G. Park, "Histopathological study of frontalis suspension materials," Japanese Journal of Ophthalmology, vol. 44, no. 2, pp. 171-174, 2000.

[25] C. D. G. Carneiro, L. U. Sennes, P. H. N. Saldiva, D. H. Tsuji, and J. A. Ximenes Filho, "Assessment of collagen deposits after implant of fascia lata and fat in the vocal folds of rabbits: histomorphometric study," Revista Brasileira de Otorrinolaringologia, vol. 71, no. 6, pp. 798-802, 2005.

[26] A. E. Krambeck, C. D. Dora, T. J. Sebo, A. L. Rohlinger, D. S. DiMarco, and D. S. Elliott, "Time-dependent variations in inflammation and scar formation of six different pubovaginal sling materials in the rabbit model," Urology, vol. 67, no. 5, pp. 1105-1110, 2006.

[27] A. J. Woodruff, E. E. Cole, R. R. Dmochowski, H. M. Scarpero, E. N. Beckman, and J. C. Winters, "Histologic comparison of pubovaginal sling graft materials: a comparative study," Urology, vol. 72, no. 1, pp. 85-89, 2008.

[28] B. de Rezende Pinna, J. N. Stavale, P. A. de Lima Pontes, and O. de Oliveira Camponês do Brasil, "Histological analysis of autologous fascia graft implantation into the rabbit voice muscle," Brazilian Journal of Otorhinolaryngology, vol. 77, no. 2, pp. 185-190, 2011.

[29] S. H. M. de Almeida, M. A. F. Rodrigues, É. Gregório, J. Crespígio, and H. A. Moreira, "Influence of sling material on inflammation and collagen deposit in an animal model," International Journal of Urology, vol. 14, no. 11, pp. 1040-1043, 2007.

[30] P. A. Moalli, “Cadaveric fascia lata," International Urogynecology Journal and Pelvic Floor Dysfunction, vol. 17, supplement 1, no. 7, pp. S48-S50, 2006.

[31] M. L. Lemer, D. C. Chaikin, and J. G. Blaivas, "Tissue strength analysis of autologous and cadaveric allografts for the pubovaginal sling," Neurourology and Urodynamics, vol. 18, no. 5, pp. 497503, 1999.

[32] A. W. McBride, R. M. Ellerkmann, A. E. Bent, and C. F. Melick, "Comparison of long-term outcomes of autologous fascia lata slings with Suspend Tutoplast fascia lata allograft slings for stress incontinence," American Journal of Obstetrics and Gynecology, vol. 192, no. 5, pp. 1677-1681, 2005.

[33] N. S. Howden, H. M. Zyczynski, P. A. Moalli, E. R. Sagan, L. A. Meyn, and A. M. Weber, "Comparison of autologous rectus fascia and cadaveric fascia in pubovaginal sling continence outcomes," The American Journal of Obstetrics and Gynecology, vol. 194, no. 5, pp. 1444-1449, 2006.

[34] A. J. Walter, A. N. Morse, K. O. Leslie, M. E. Zobitz, J. G. Hentz, and J. L. Cornella, "Changes in tensile strength of cadaveric human fascia lata after implantation in a rabbit vagina model," The Journal of Urology, vol. 169, no. 5, pp. 1907-1910, 2003.

[35] P. E. Spiess, D. Rabah, C. Herrera, G. Singh, R. Moore, and J. Corcos, "The tensile properties of tension-free vaginal tape and cadaveric fascia lata in an in vivo rat model," BJU International, vol. 93, no. 1, pp. 171-173, 2004.

[36] R. D. Rice, F. S. Ayubi, Z. J. Shaub, D. M. Parker, P. J. Armstrong, and J. W. Tsai, "Comparison of surgisis, AlloDerm, and Vicryl
Woven Mesh grafts for abdominal wall defect repair in an animal model," Aesthetic Plastic Surgery, vol. 34, no. 3, pp. 290296, 2010.

[37] A. P. Sclafani, T. Romo III, A. A. Jacono, S. McCormick, R. Cocker, and A. Parker, "Evaluation of acellular dermal graft in sheet (AlloDerm) and injectable (micronized AlloDerm) forms for soft tissue augmentation. Clinical observations and histological analysis," Archives of Facial Plastic Surgery, vol. 2, no. 2, pp. 130-136, 2000.

[38] A. Yildirim, E. K. Basok, T. Gulpinar, C. Gurbuz, E. Zemheri, and R. Tokuc, "Tissue reactions of 5 sling materials and tissue material detachment strength of 4 synthetic mesh materials in a rabbit model," The Journal of Urology, vol. 174, no. 5, pp. 20372040, 2005.

[39] P. J. VandeVord, K. M. Broadrick, B. Krishnamurthy, and A. K. Singla, "A comparative study evaluating the in vivo incorporation of biological sling materials," Urology, vol. 75, no. 5, pp. 1228-1233, 2010.

[40] C. M. Kolb, L. M. Pierce, and S. B. Roofe, "Biocompatibility comparison of novel soft tissue implants vs commonly used biomaterials in a pig model," Otolaryngology-Head and Neck Surgery, vol. 147, no. 3, pp. 456-461, 2012.

[41] C. D. Richters, A. Pirayesh, H. Hoeksema et al., "Development of a dermal matrix from glycerol preserved allogeneic skin," Cell and Tissue Banking, vol. 9, no. 4, pp. 309-315, 2008.

[42] K. V. Amrute and G. H. Badlani, "The science behind biomaterials in female stress urinary incontinence surgery," TheScientificWorldJournal, vol. 9, pp. 23-31, 2009.

[43] J. C. Winters, "InteXen tissue processing and laboratory study," International Urogynecology Journal and Pelvic Floor Dysfunction, vol. 17, supplement 1, pp. S34-S38, 2006.

[44] M. Lucas, S. Emery, W. Alan, and W. Kathy, "Failure of porcine xenograft sling in a randomised controlled trial of three sling materials in surgery for stress incontience," in Proceedings of the International Continence Society (34th Annual Meeting) and the International UroGynecological Association, Paris, France, 2004.

[45] J. S. Jones, R. R. Rackley, R. Berglund, J. B. Abdelmalak, G. Deorco, and S. P. Vasavada, "Porcine small intestinal submucosa as a percutaneous mid-urethral sling: 2-year results," $B J U$ International, vol. 96, no. 1, pp. 103-106, 2005.

[46] A. B. Rutner, S. R. Levine, and J. F. Schmaelzle, "Processed porcine small intestine submucosa as a graft material for pubovaginal slings: durability and results," Urology, vol. 62, no. 5, pp. 805-809, 2003.

[47] M.-H. Zheng, J. Chen, Y. Kirilak, C. Willers, J. Xu, and D. Wood, "Porcine small intestine submucosa (SIS) is not an acellular collagenous matrix and contains porcine DNA: possible implications in human implantation," Journal of Biomedical Materials Research B: Applied Biomaterials, vol. 73, no. 1, pp. 61-67, 2005.

[48] L. M. Pierce, M. A. Grunlan, Y. Hou, S. S. Baumann, T. J. Kuehl, and T. W. Muir, "Biomechanical properties of synthetic and biologic graft materials following long-term implantation in the rabbit abdomen and vagina," American Journal of Obstetrics \& Gynecology, vol. 200, no. 5, pp. 549.e1-549.e8, 2009.

[49] Z. Liu, R. Tang, Z. Zhou, Z. Song, H. Wang, and Y. Gu, "Comparison of two porcine-derived materials for repairing abdominal wall defects in rats," PLoS ONE, vol. 6, no. 5, Article ID e20520, 2011.

[50] M. L. Konstantinovic, P. Lagae, F. Zheng, E. K. Verbeken, D. de Ridder, and J. A. Deprest, "Comparison of host response to polypropylene and non-cross-linked porcine small intestine 
serosal-derived collagen implants in a rat model," BJOG, vol.112, no. 11, pp. 1554-1560, 2005.

[51] F. Zhang, J. Zhang, S. Lin et al., "Small intestinal submucosa in abdominal wall repair after TRAM flap harvesting in a rat model," Plastic and Reconstructive Surgery, vol. 112, no. 2, pp. 565-570, 2003.

[52] S. Badylak, K. Kokini, B. Tullius, and B. Whitson, "Strength over time of a resorbable bioscaffold for body wall repair in a dog model," Journal of Surgical Research, vol. 99, no. 2, pp. 282-287, 2001.

[53] E. D. Jenkins, L. Melman, C. R. Deeken, S. C. Greco, M. M. Frisella, and B. D. Matthews, "Biomechanical and histologic evaluation of fenestrated and nonfenestrated biologic mesh in a porcine model of ventral hernia repair," Journal of the American College of Surgeons, vol. 212, no. 3, pp. 327-339, 2011.

[54] R. Ko, E. A. Kazacos, S. Snyder, D. M. J. Ernst, and G. C. Lantz, "Tensile strength comparison of small intestinal submucosa body wall repair," Journal of Surgical Research, vol. 135, no. 1, pp. 9-17, 2006.

[55] S. Badylak, K. Kokini, B. Tullius, A. Simmons-Byrd, and R. Morff, "Morphologic study of small intestinal submucosa as a body wall repair device," Journal of Surgical Research, vol. 103, no. 2, pp. 190-202, 2002.

[56] A. Wiedemann and M. Otto, "Small intestinal submucosa for pubourethral sling suspension for the treatment of stress incontinence: first histopathological results in humans," The Journal of Urology, vol. 172, no. 1, pp. 215-218, 2004.

[57] B. K. Poulose, S. Scholz, D. E. Moore et al., "Physiologic properties of small intestine submucosa," Journal of Surgical Research, vol. 123, no. 2, pp. 262-267, 2005.

[58] M. Thiel, P. C. Rodrigues Palma, C. L. Z. Riccetto, M. Dambros, and N. R. Netto Jr., "A stereological analysis of fibrosis and inflammatory reaction induced by four different synthetic slings," BJU International, vol. 95, no. 6, pp. 833-837, 2005.

[59] M. S. Kim, H. H. Ahn, Y. N. Shin, M. H. Cho, G. Khang, and H. B. Lee, "An in vivo study of the host tissue response to subcutaneous implantation of PLGA- and/or porcine small intestinal submucosa-based scaffolds," Biomaterials, vol. 28, no. 34, pp. 5137-5143, 2007.

[60] E. Cole, A. Gomelsky, and R. R. Dmochowski, "Encapsulation of a porcine dermis pubovaginal sling," Journal of Urology, vol. 170, no. 5, p. 1950, 2003.

[61] J. Deprest, B. Klosterhalfen, A. Schreurs, J. Verguts, D. De Ridder, and F. Claerhout, "Clinicopathological study of patients requiring reintervention after sacrocolpopexy with xenogenic acellular collagen grafts," The Journal of Urology, vol. 183, no. 6, pp. 2249-2255, 2010.

[62] T. M. Macleod, G. Williams, R. Sanders, and C. J. Green, "Histological evaluation of Permacol as a subcutaneous implant over a 20-week period in the rat model," British Journal of Plastic Surgery, vol. 58, no. 4, pp. 518-532, 2005.

[63] T. P. Rauth, B. K. Poulose, L. B. Nanney, and M. D. Holzman, "A comparative analysis of expanded polytetrafluoroethylene and small intestinal submucosa-implications for patch repair in ventral herniorrhaphy," Journal of Surgical Research, vol. 143, no. 1, pp. 43-49, 2007.

[64] M. Sandor, H. Xu, J. Connor et al., "Host response to implanted porcine-derived biologic materials in a primate model of abdominal wall repair," Tissue Engineering Part A, vol. 14, no. 12, pp. 2021-2031, 2008.

[65] L. M. Pierce, A. Rao, S. S. Baumann, J. E. Glassberg, T. J. Kuehl, and T. W. Muir, "Long-term histologic response to synthetic and biologic graft materials implanted in the vagina and abdomen of a rabbit model," The American Journal of Obstetrics and Gynecology, vol. 200, no. 5, pp. 546.el-546.e8, 2009.

[66] K. A. Daly, S. Liu, V. Agrawal et al., "The host response to endotoxin-contaminated dermal matrix," Tissue EngineeringPart A, vol. 18, no. 11-12, pp. 1293-1303, 2012.

[67] M. A. Suckow, W. R. Wolter, C. Fecteau, S. M. LabadieSuckow, and C. Johnson, "Bupivacaine-enhanced small intestinal submucosa biomaterial as a hernia repair device," Journal of Biomaterials Applications, vol. 27, no. 2, pp. 231-237, 2012.

[68] A. Gomelsky and R. R. Dmochowski, "Biocompatibility assessment of Synthetic Sling Materials for Female Stress Urinary Incontinence," Journal of Urology, vol. 178, no. 4, pp. 1171-1181, 2007.

[69] P. K. Amid, "Classification of biomaterials and their related complications in abdominal wall hernia surgery," Hernia, vol. 1, no. 1, pp. 15-21, 1997.

[70] M. W. Weinberger and D. R. Ostergard, "Postoperative catheterization, urinary retention, and permanent voiding dysfunction after polytetrafluoroethylene suburethral sling placement," Obstetrics and Gynecology, vol. 87, no. 1, pp. 50-54, 1996.

[71] S. B. Young, A. E. Howard, and S. P. Baker, "Mersilene mesh sling: short- and long-term clinical and urodynamic outcomes," American Journal of Obstetrics \& Gynecology, vol. 185, no. 1, pp. 32-40, 2001.

[72] J. C. Winters, M. P. Fitzgerald, and M. D. Barber, "The use of synthetic mesh in female pelvic reconstructive surgery," BJU International, vol. 98, no. 1, pp. 70-77, 2006.

[73] M. Slack, J. S. Sandhu, D. R. Staskin, and R. C. Grant, "In vivo comparison of suburethral sling materials," International Urogynecology Journal and Pelvic Floor Dysfunction, vol. 17, no. 2, pp. 106-110, 2006.

[74] K. C. Zorn, P. E. Spiess, G. Singh, M. A. Orvieto, B. Moore, and J. Corcos, "Long-term tensile properties of tension-free vaginal tape, suprapubic arc sling system and urethral sling in an in vivo rat model," The Journal of Urology, vol. 177, no. 3, pp. 1195-1198, 2007.

[75] M. Boukerrou, L. Boulanger, C. Rubod, E. Lambaudie, P. Dubois, and M. Cosson, "Study of the biomechanical properties of synthetic mesh implanted in vivo," European Journal of Obstetrics Gynecology and Reproductive Biology, vol. 134, no. 2, pp. 262-267, 2007.

[76] T. M. Bazi, R. F. Hamade, I. A. H. Hussein, K. A. Nader, and A. Jurjus, "Polypropylene midurethral tapes do not have similar biologic and biomechanical performance in the rat," European Urology, vol. 51, no. 5, pp. 1364-1375, 2007.

[77] L. Melman, E. D. Jenkins, N. A. Hamilton et al., "Histologic and biomechanical evaluation of a novel macroporous polytetrafluoroethylene knit mesh compared to lightweight and heavyweight polypropylene mesh in a porcine model of ventral incisional hernia repair," Hernia, vol. 15, no. 4, pp. 423-431, 2011.

[78] S. Manodoro, M. Endo, P. Uvin et al., "Graft-related complications and biaxial tensiometry following experimental vaginal implantation of flat mesh of variable dimensions," BJOG, vol. 120, no. 2, pp. 244-250, 2013.

[79] H. P. Dietz, P. Vancaillie, M. Svehla, W. Walsh, A. B. Steensma, and T. G. Vancaillie, "Mechanical properties of urogynecologic implant materials," International Urogynecology Journal and Pelvic Floor Dysfunction, vol. 14, no. 4, pp. 239-243, 2003.

[80] U. Klinge, B. Klosterhalfen, V. Birkenhauer, K. Junge, J. Conze, and V. Schumpelick, "Impact of polymer pore size on the 
interface scar formation in a rat model," Journal of Surgical Research, vol. 103, no. 2, pp. 208-214, 2002.

[81] F. Zheng, Y. Lin, E. Verbeken et al., "Host response after reconstruction of abdominal wall defects with porcine dermal collagen in a rat model," The American Journal of Obstetrics and Gynecology, vol. 191, no. 6, pp. 1961-1970, 2004.

[82] F. Spelzini, M. L. Konstantinovic, I. Guelinckx et al., “Tensile strength and host response towards silk and type I polypropylene implants used for augmentation of fascial repair in a rat model," Gynecologic and Obstetric Investigation, vol. 63, no. 3, pp. 155-162, 2007.

[83] M. Bogusiewicz, A. Wróbel, K. Jankiewicz et al., "Collagen deposition around polypropylene tapes implanted in the rectus fascia of female rats," European Journal of Obstetrics Gynecology and Reproductive Biology, vol. 124, no. 1, pp. 106-109, 2006.

[84] D. M. Rabah, L. R. Bégin, A. Zahran, and J. Corcos, "Tissue reactions of the rabbit urinary bladder to cadaveric human fascia lata and polypropylene surgical mesh," The Canadian Journal of Urology, vol. 11, no. 4, pp. 2344-2349, 2004.

[85] G. Pascual, M. Rodríguez, S. Sotomayor, B. Pérez-Köhler, and J. M. Bellón, "Inflammatory reaction and neotissue maturation in the early host tissue incorporation of polypropylene prostheses," Hernia, vol. 16, no. 6, pp. 697-707, 2012.

[86] R. K. Huffaker, T. W. Muir, A. Rao, S. S. Baumann, T. J. Kuehl, and L. M. Pierce, "Histologic response of porcine collagencoated and uncoated polypropylene grafts in a rabbit vagina model," The American Journal of Obstetrics and Gynecology, vol. 198, no. 5, pp. 582.el-582.e7, 2008.

[87] L. Boulanger, M. Boukerrou, E. Lambaudie, A. Defossez, and M. Cosson, "Tissue integration and tolerance to meshes used in gynecologic surgery: an experimental study," European Journal of Obstetrics \& Gynecology and Reproductive Biology, vol. 125, no. 1, pp. 103-108, 2006.

[88] R. Tayrac, A. Alves, and M. Thérin, "Collagen-coated vs noncoated low-weight polypropylene meshes in a sheep model for vaginal surgery. A pilot study," International Urogynecology Journal, vol. 18, no. 5, pp. 513-520, 2007.

[89] C. Falconer, M. Söderberg, B. Blomgren, and U. Ulmsten, "Influence of different sling materials on connective tissue metabolism in stress urinary incontinent women," International Urogynecology Journal and Pelvic Floor Dysfunction, vol. 12, no. 2, pp. S19-S23, 2001.

[90] A. C. Wang, L. Y. Lee, C. T. Lin, and J. R. Chen, "A histologic and immunohistochemical analysis of defective vaginal healing after continence taping procedures: a prospective casecontrolled pilot study," American Journal of Obstetrics and Gynecology, vol. 191, no. 6, pp. 1868-1874, 2004.

[91] C. Elmer, B. Blomgren, C. Falconer, A. Zhang, and D. Altman, "Histological inflammatory response to transvaginal polypropylene mesh for pelvic reconstructive surgery," The Journal of Urology, vol. 181, no. 3, pp. 1189-1195, 2009.

[92] F. E. Govier, K. C. Kobashi, D. D. Kuznetsov et al., "Multicenter prospective study of the long-term effectiveness of a silicone coated synthetic mesh sling," Journal of Urology, vol. 171, supplement 4, pp. 92-93, 2005.

[93] A. Mangera, A. J. Bullock, C. R. Chapple, and S. MacNeil, "Are biomechanical properties predictive of the success of prostheses used in stress urinary incontinence and pelvic organ prolapse? A systematic review," Neurourology and Urodynamics, vol. 31, no. 1, pp. 13-21, 2012.

[94] A. Feola, S. Abramowitch, Z. Jallah et al., "Deterioration in biomechanical properties of the vagina following implantation of a high-stiffness prolapse mesh," BJOG, vol. 120, no. 2, pp. 224232, 2013.

[95] A. Remes and D. F. Williams, "Immune response in biocompatibility," Biomaterials, vol. 13, no. 11, pp. 731-743, 1992.

[96] M. T. Wolf, C. L. Dearth, C. A. Ranallo et al., "Macrophage polarization in response to ECM coated polypropylene mesh," Biomaterials, vol. 35, no. 25, pp. 6838-6849, 2014.

[97] A. Kligman and R. Gollhausen, "The "angry back": a new concept or old confusion?" British Journal of Dermatology, vol. 115, no. 31, pp. 93-100, 1986.

[98] B. M. Sicari, J. P. Rubin, C. L. Dearth et al., "An acellular biologic scaffold promotes skeletal muscle formation in mice and humans with volumetric muscle loss," Science Translational Medicine, vol. 6, no. 234, Article ID 234ra58, 2014.

[99] H. Patel, D. R. Ostergard, and G. Sternschuss, "Polypropylene mesh and the host response," International Urogynecology Journal and Pelvic Floor Dysfunction, vol. 23, no. 6, pp. 669-679, 2012.

[100] J. Deprest and A. Feola, "The need for preclinical research on pelvic floor reconstruction," BJOG: An International Journal of Obstetrics and Gynaecology, vol. 120, no. 2, pp. 141-143, 2013.

[101] M. E. Karlovsky, L. Kushner, and G. H. Badlani, "Synthetic biomaterials for pelvic floor reconstruction," Current Urology Reports, vol. 6, no. 5, pp. 376-384, 2005.

[102] C. R. Chapple, S. Raz, L. Brubaker, and P. E. Zimmern, "Mesh sling in an era of uncertainty: lessons learned and the way forward," European Urology, vol. 64, no. 4, pp. 525-529, 2013. 


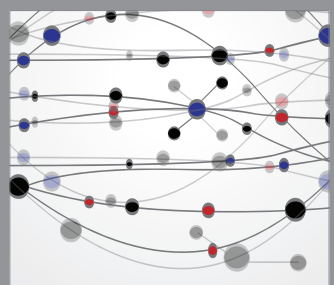

The Scientific World Journal
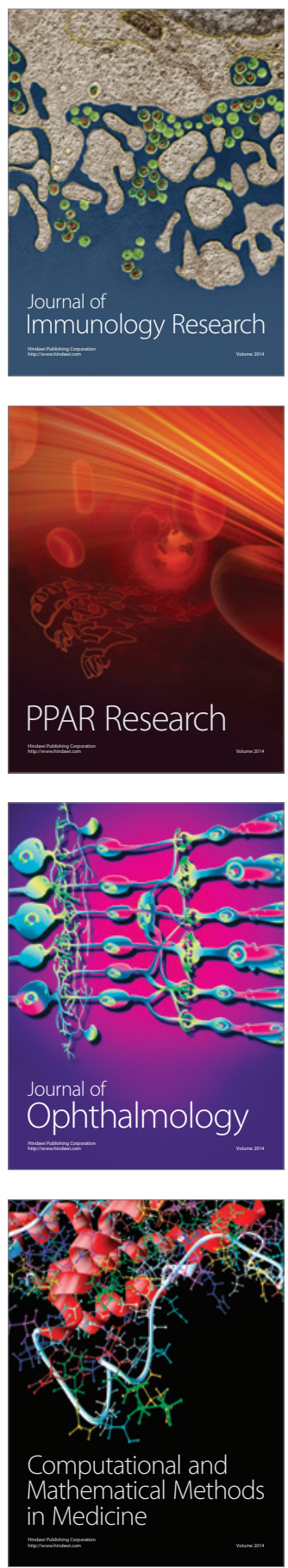

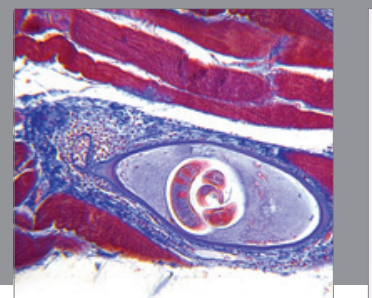

Gastroenterology

Research and Practice
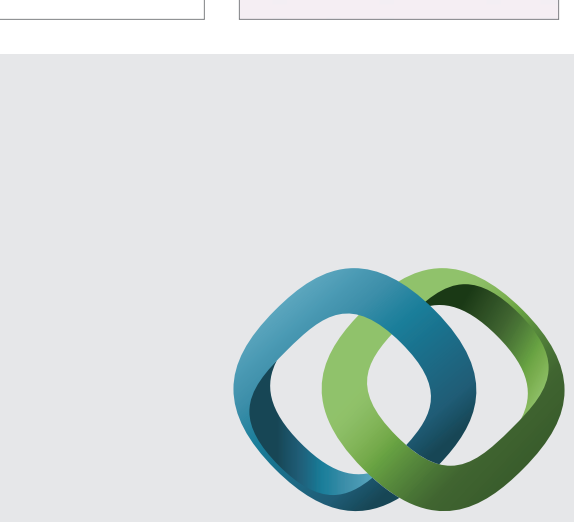

\section{Hindawi}

Submit your manuscripts at

http://www.hindawi.com
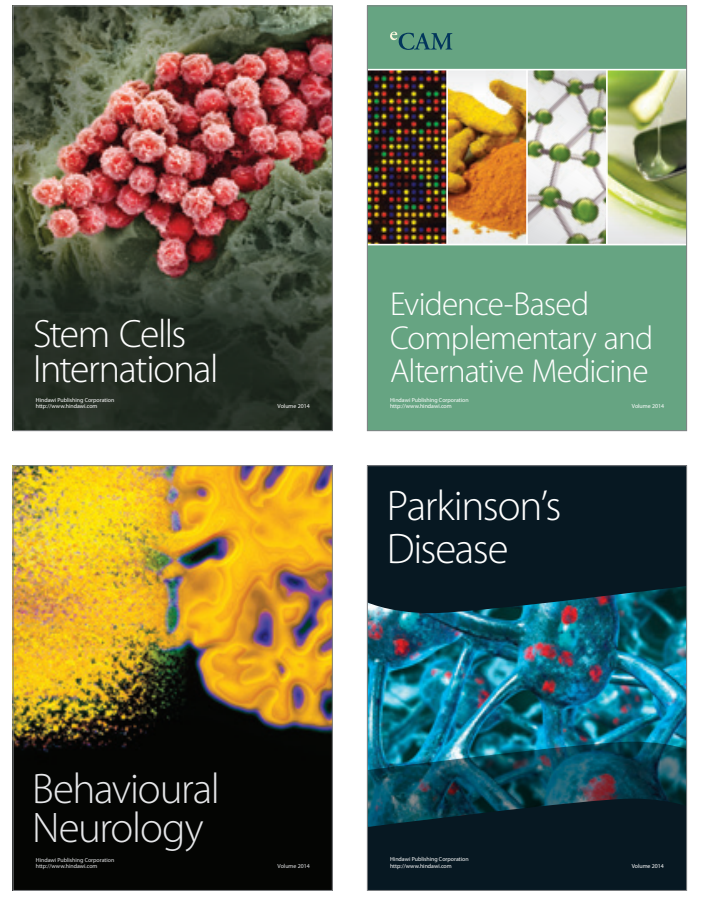
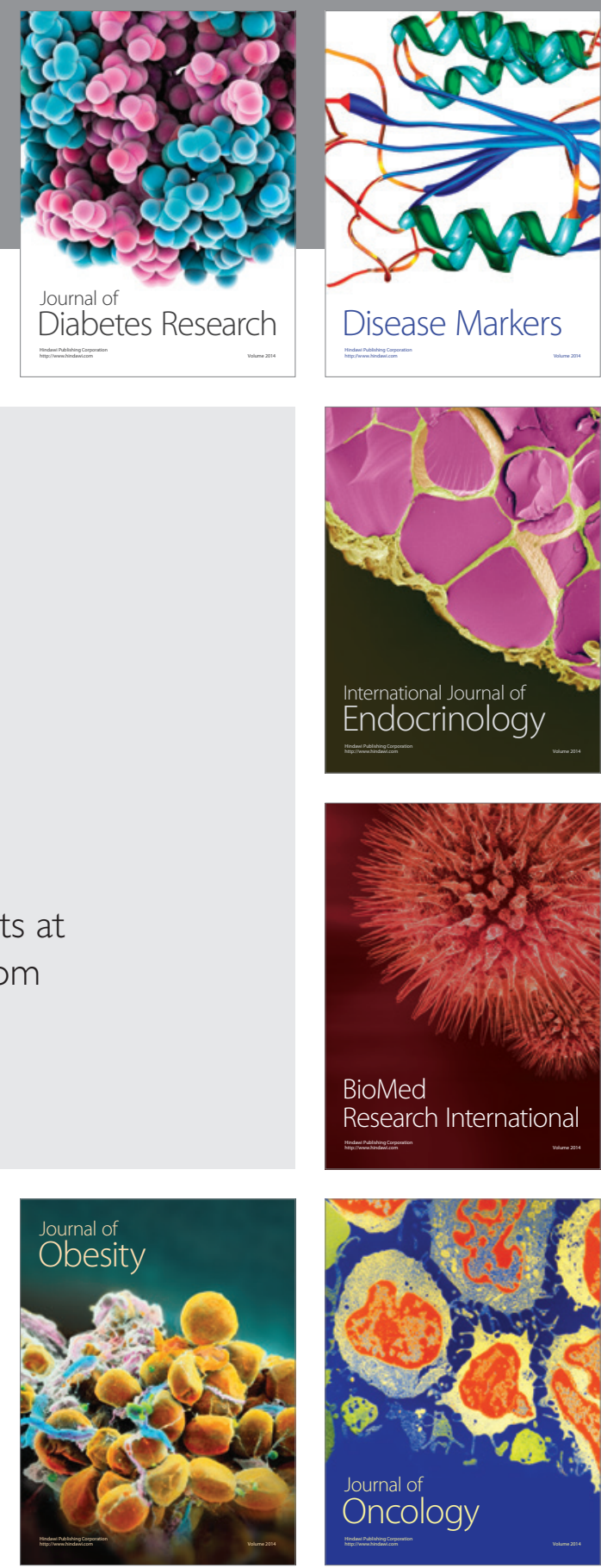

Disease Markers
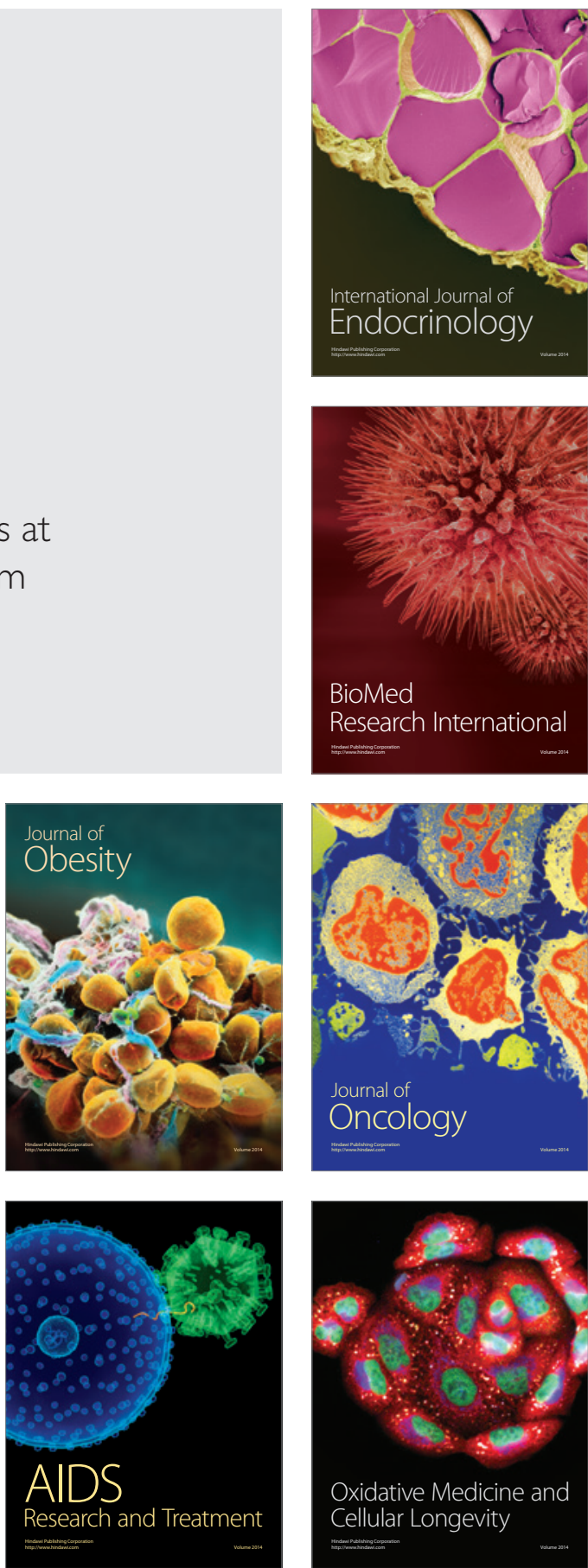